\title{
Integrated socio-hydrogeological approach to tackle nitrate contamination in groundwater resources. The case of Grombalia Basin (Tunisia).
}

\author{
Re V. ${ }^{1,2}$, Sacchi E. ${ }^{3}$, Kammoun S. ${ }^{1}$, Tringali C. ${ }^{2}$, Trabelsi R. ${ }^{1}$, Zouari K. ${ }^{1}$, Daniele $S .{ }^{2}$ \\ ${ }^{1} 1$ Laboratory of Radio-Analyses and Environment, National School of Engineers of Sfax, BP1173, \\ 3038 Sfax, Tunisia \\ ${ }^{2}$ Department of Molecular Sciences and Nanosystems, Ca' Foscari University of Venice, Via Torino \\ 155 - 30172, Mestre-Venezia, Italy \\ email: re@unive.it \\ Fax: +390412348591 \\ ${ }^{3}$ Department of Earth and Environmental Sciences, University of Pavia, Via Ferrata 1, 27100 Pavia, \\ Italy
}

\begin{abstract}
Nitrate contamination still remains one of the main groundwater quality issues in several aquifers worldwide, despite the perduring efforts of the international scientific community to effectively tackle this problem. The classical hydrogeological and isotopic investigations are obviously of paramount importance for the characterization of contaminant sources, but are clearly not sufficient for the correct and long-term protection of groundwater resources. This paper aims at demonstrating the effectiveness of the socio-hydrogeological approach as the best tool to tackle groundwater quality issues, while contributing bridging the gap between science and society. An integrated survey, including land use, hydrochemical (physicochemical parameters and major ions) and isotopic $\left(\delta^{15} \mathrm{~N}_{\mathrm{NO}}\right.$ and $\left.\delta^{18} \mathrm{O}_{\mathrm{NO}}\right)$ analyses, coupled to capacity building and participatory activities was carried out to correctly attribute the nitrate origin in groundwater from the Grombalia Basin (North Tunisia), a region where only synthetic fertilizers have been generally identified as the main source of such pollution. Results demonstrates that the basin is characterized by high nitrate concentrations, often exceeding the statutory limits for drinking water, in both the shallow and deep aquifers, whereas sources are associated to both agricultural and urban activities.

The public participation of local actors proved to be a fundamental element for the development of the hydrogeological investigation, as it permitted to obtain relevant information to support data interpretation, and eventually guaranteed the correct assessment of contaminant sources in the studied area. In addition, such activity, if adequately transferred to regulators, will ensure the effective adoption of management practices based on the research outcomes and tailored on the real needs of the local population, proving the added value to include it in any integrated investigation.
\end{abstract}

Keywords: Socio-hydrogeology, aquifer pollution, isotopes, public engagement, stakeholder analysis 


\section{Introduction}

2 A stronger integration between science and society could contribute solving nitrate contamination issues affecting rural regions worldwide. In these areas groundwater often represents the main freshwater source for both domestic and agricultural uses, providing farms and local households with -generally- free supplies in close proximity to the users and commonly without the need for complex treatment (Morris et al., 2003). Accordingly, worldwide $49 \%$ of the rural population depends on groundwater for domestic supply mostly extracted from private boreholes and/or hand dug wells (UNICEF and WHO, 2012). In addition, approximately $38 \%$ of global irrigated areas rely on groundwater resources (Siebert et al., 2013), which has contributed to a ten-fold increase of groundwater abstraction for agricultural irrigation over the last 50 years 10 (WWAP, 2016).

Undoubtedly one of the main consequences of this high aquifer dependency is that any contamination of these waters can have serious repercussions on local population, either directly, when groundwater is used for drinking purposes or indirectly (e.g. affecting food security).

14 The intensification of agriculture to sustain human needs, occurred since the second half of the twentieth century, positively contributed to improve the wellbeing of many developing countries, where agriculture is a fundamental part of the economy (Hazell and Wood, 2008). On the other hand, however, the need to respond to rapid population growth and the shift towards more water-dependent economies resulted in severe aquifer exploitation and contamination, the latter mainly associated to high fertilizers use rates (Foster and Chilton, 2003), contributing to increase the adverse impacts of agriculture on underlying groundwater resources. As a result, rural population is primarily affected by groundwater pollution, shown by an overall enhanced mineralization generally associated to nitrate contamination (FAO, 1996). In fact, $\mathrm{N}$-compounds are among the principal nutrients provided by synthetic fertilizers and manure spread on soils to improve crop growth and development, eventually increasing the grain/seed yield (Bose and Srivastava, 2011). However, mismanaged fertilizers use and irrigation practices can lead to an accumulation of nitrates in the subsoil that can leach into the aquifer, contribute to groundwater quality degradation, especially in shallow aquifers (Singh et al., 1995), and trigger complex water-rock interaction processes, ultimately enhancing salinization, particularly in coastal aquifers (Re and Sacchi, 2017, and references therein). In fact, when too large amounts of fertilizers are used (i.e. abundantly exceeding their use efficiency, as the percent recovery of fertilizer- $\mathrm{N}$ by a crop), a significant fraction of $\mathrm{N}$ can remain unutilized in the soil and create the potential for aquifer contamination. This is the case of many rural areas, especially in developing countries, where agricultural-led nitrate contamination is often associated to other anthropogenic

32 sources (e.g. animal manure, sewage effluents, and untreated wastewaters) jointly increasing $\mathrm{N}$ 33 concentration in groundwater bodies (Keeney, 1989). For example, in the sub-urban and rural areas of the

34 Cap Vert Peninsula in the Dakar region, Senegal the interaction of agricultural activities, wastewater and 35 septic effluent infiltration cause the occurrence of high nitrate concentrations in water for irrigation and human 36 consumption, largely exceeding the statutory limits for drinking water (50 mg/L; WHO, 2011) and reaching 37 concentrations up to 800 mg/L (Deme et al., 2006; Re et al., 2011; Diédhiou et al., 2012). High groundwater 
nitrate concentrations, both industrial and agricultural origin, have also been recorded in many rural areas in China, with concentrations up to $560 \mathrm{mg} / \mathrm{L}$ found in high-yielding areas of northern China (Liu et al., 2005; Yu et al., 2015, and references therein). In other regions the agricultural impact can be considered negligible, if compared with the on-site sanitation contribution. This is the case for example of different urban/peri-urban areas and high-density rural settlements in South Africa, Namibia and Botswana, where this anthropogenic source causes the occurrence of nitrate concentrations exceeding $800 \mathrm{mg} / \mathrm{L}$ (Tredoux et al., 2009). In these situations, nitrate contamination of groundwater goes beyond the issue of water resources conservation per se, but also becomes a strong economic and social concern, given the severe impacts that excess of nitrates in groundwater can have on local populations, potentially arising food security and health (i.e gastric cancer and methemoglobinemia in infants; Fan and Steinberg, 1996) issues. In addition, nitrate pollution, according to its origin, it's often associated with other contaminants, as pesticides or coliforms, therefore evidencing the aquifer vulnerability. This is why over the years the international scientific community widely analysed these effects and worked towards finding methods to identify the sources of contamination, such as the application of environmental isotopes (e.g. $\delta^{15} \mathrm{~N}_{\mathrm{NO} 3}$ and $\delta^{18} \mathrm{O}_{\mathrm{NO}}$; Aravena et al., 1993; Panno et

al., 2001; Baily et al., 2011).

53 So why nitrate pollution continues being such a great issue worldwide? Why farmers continue over applying 54 fertilizers and mismanage farm manure? Why local authorities underestimate the effects of the lack of proper sewage collection and treatment facilities on the subsoil and groundwater quality? This can be partially attributed to the "hidden nature" of both groundwater resources and nitrate contamination (i.e. odourless, absence of unpleasant taste, colour or turbidity), that makes more difficult its identification without specific analysis. But, leaving aside limitations in governance and central-local relations, which are out of the scope of this research, it is clear that a gap between the scientific community and the water endusers/managers/polluters still hampers adequate capacity building and knowledge transfer in this regard. The main effect of this fault is therefore the lack of awareness not only on the strong connections between human activities and the quality of the natural environment, but also on the fact that groundwater protection can lead to long-term benefits from the socio-economic point of view. This is why it is nowadays unrealistic to obtain effective solutions to water (and more generally environmental) issues keeping hydrogeology (and science) separate from the socio-economic and political domain. It is clearly important that the risks to groundwater quality (and consequently to human health) by the widespread use of fertilizers and unconstrained water use are assessed, so that the necessary control measures can be introduced. Nevertheless, effective durable solutions can not be implemented without coupling sound scientific assessments with adequate public engagement and capacity building on the importance of water resources protection. In this regards it is crucial to strengthen the interactions between scientists and both farmers and water users, in order to make the most effective use of the outcomes of hydrogeological and environmental investigations tailored to water security. This implies bridging the gap between science policy and society, based on the assumption that a common understanding of the implication of scientific research would help solving the issues arising from opposing perceptions of environmental matters (Busche, 2015). Thus, improving information sharing and public engagement when different interests are at stake would be an asset in any research willing to lead to 
effective governance measures also in the groundwater sector. In this framework a new approach was proposed by $\operatorname{Re}(2015)$, named socio-hydrogeology, as a way of incorporating the social dimension into hydrogeological investigations and calling for a stronger engagement of hydrogeologists as advocates for public participation in water management and governance. In line with socio-hydrology (Sivapalan et al., 2012), aimed at studying the dynamic interactions and feedbacks between water and people, sociohydrogeology focuses on the understanding of the mutual relations between people and groundwater (i.e., the impact of human activities on aquifer quality and the impact of groundwater on human wellbeing and life), by fostering the inclusion of the social dimension in hydrogeological investigations.

84 This paper aims at promoting the implementation of socio-hydrogeological approach as the best tool to tackle groundwater quality assessment, while contributing bridging the gap between science and society, by presenting the results of a research undertaken in the Grombalia Basin (North Tunisia). In particular, the effectiveness of performing specific groundwater quality assessments together with capacity building and participatory activities is tested. The public participation of local actors is a fundamental element for the development of the hydrogeological investigation, as it may ensure the effective adoption of management practices based on the research outcomes and tailored on the real needs of the local population. In this regard, direct engagement and confrontation with well owners and farmers allows hydrogeologists to tackle the investigation more productively, to retrieve reliable information on water and land use, and to create a relationship of mutual trust with local stakeholders. Hence the manuscript examines whether incorporating structured questionnaire administration to local farmers while performing hydrogeological samplings can value the effort, although it may seem time and money consuming. Indeed, these activities can provide precious information, useful for data interpretation, and at the same time favour dissemination and capacity building to support the implementation of new management practices based on the results of the scientific investigation.

\section{Site description}

101 The Grombalia region is located in south-western part of the Cap Bon Peninsula (Tunisia) and covers a 102 surface of about $719 \mathrm{~km}^{2}$. The basin is bordered by the Gulf of Tunis (N), the Takelsa Syncline (N-E), the

103 anticlinal of the Abderrahmene Mountain and the oriental coastal plain (E), the plain of Hammamet (S) and 104 the Bouchoucha and Halloufa reliefs (W; Figure 1).

105 The climate of the region is semi-arid to Mediterranean sub-humid, with average precipitations of about 500 $106 \mathrm{~mm} / \mathrm{y}$ (1954-2006; DGRE, 2006), with maximum precipitations between October and January, and mean 107 annual temperature of around $18{ }^{\circ} \mathrm{C}\left(\max 28.9^{\circ} \mathrm{C}\right.$ in July, $\min 8.6{ }^{\circ} \mathrm{C}$ in January; 2003-2013, INM, 2014). 108 The average monthly potential evapotranspiration is $76.8 \mathrm{~mm}$, with lowest value in January $(40.7 \mathrm{~mm})$ and 109 the maximum in July (134.5) (2003-2012; INM, 2014). In the area several ephemeral rivers (wadis) are 110 present, collecting surface runoff from the surrounding highlands toward the Gulf of Tunis.

111 The Grombalia Basin is situated astride the African-Eurasian plate boundary (Elmejdoub and Jedoui 2009). 112 Geologically, it is described as a graben delimited by two normal faults developed during the Middle Miocene 
113 (Hadj Sassi et al. 2006), namely the Borj Cedria NNW-SSE normal fault and the Hammamet NE-SW normal 114 fault (Ben Ayed 1993; Ben Salem 1995; Chihi 1995) and filled by 500 m of Quaternary sediments. These 115 mainly consist of fine to coarse grained sands, clayey sands, sandstone, silt and abundant evaporate 116 deposits (Schoeller, 1939; Colleuil, 1976; Ben Salem, 1995; Ben Moussa et al., 2010).

117 From a hydrogeologic point of view, the Grombalia aquifer is a multi-layer system constituted by a shallow 118 phreatic aquifer, with an average thickness of about $50 \mathrm{~m}$, hosted in the Quaternary continental sand, clayey 119 sand and sandstones deposits, and different confined aquifers with average thickness of about $100 \mathrm{~m}$ each 120 separated by marl layers but communicating through discontinuities (Castany, 1948; Ennabli, 1980). The 121 recharge in the shallow unconfined aquifer mainly occurs in the pediments of the surrounding mountains and 122 converges to the central part of the basin. There, a general southeast-northwest flow carries groundwater to 123 the Gulf of Tunis discharge areas (Ben Moussa 2007; Gaaloul et al., 2014).

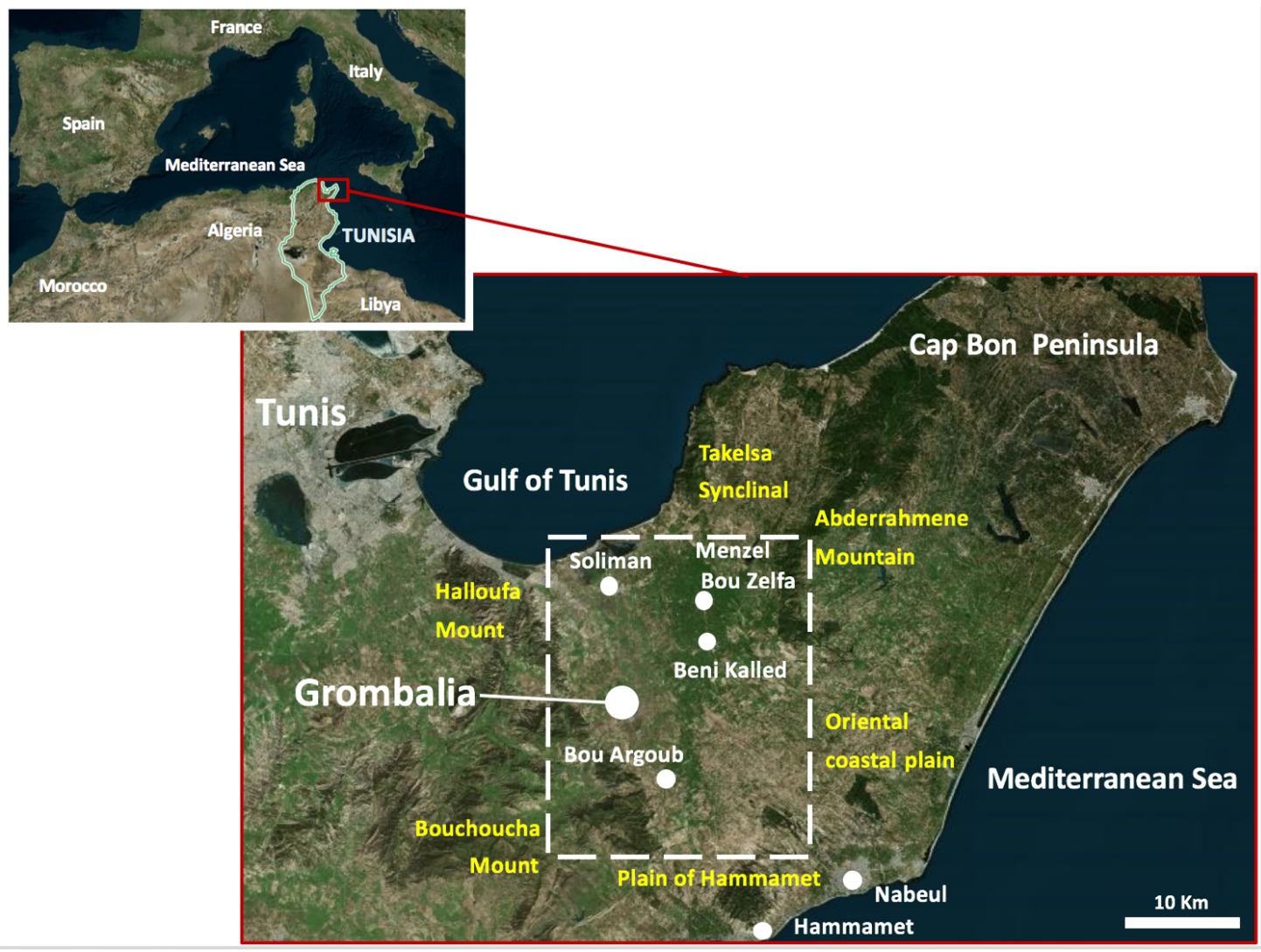

125 Figure 1. Location of the Grombalia Basin. Background satellite image from Microsoft $\circledast$ Bing ${ }^{\mathrm{TM}}$ Maps. The white 126 rectangle highlights the area represented in Figure 2.

128 The Gombalia region is particularly devoted to arboriculture (mainly citrus -representing $82 \%$ of the national 129 production-, grapes $-80 \%$ of Tunisian vineyards- and olives) and horticulture (mainly tomatoes, strawberries 130 and legumes). Most of the agricultural production, if not used for personal consumption, is sold on both the 131 national and international markets (Gafsi and Ben Hadj, 2007), and the agro-industrial sector is also rapidly 
132 expanding with more than 1250 factories, including food processing plants located in surrounding areas of 133 Nabeul, Grombalia and Soliman.

134 In the region, groundwater represents the main source of water supply for both agricultural and industrial use,

135 and consequently, the aquifer is increasingly exposed to external pressure. More than 11,000 wells tap the

136 shallow aquifer, with a current abstraction around $250 \mathrm{Mm}^{3} / \mathrm{y}$, causing an estimated decrease of the water 137 table depth of about $0.3 \mathrm{~m} / \mathrm{y}$ (DGRE 2010). Aquifer overexploitation had led to a severe piezometric level 138 decrease over the years ( about $10 \mathrm{~m}$ in the last 50 years; Charfi et al. 2013a; Gaaloul et al. 2014), that is 139 especially evident during the dry months, when abstraction rates exceed natural aquifer recharge from rainfall 140 infiltration. In addition to scarcity, groundwater quality depletion is increasingly harming natural water 141 resources. The latter is generally associated to aquifer salinization, salt water intrusion near to the sea shore 142 and nitrate pollution due to anthropogenic activities (Ben Moussa et al., 2010; Ben Moussa and Zouari, 143 2011). As multiple contamination sources are present in the region of Grombalia, it is fundamental not only to 144 clearly identify them, but also to effectively raise awareness among all the concerned stakeholders in order to 145 promote shared strategies for contamination reduction and remediation, based both on sound scientific 146 results and participative processes.

\section{3. Methods}

149 A socio-hydrogeological investigation, combining both classical hydrogeological analusis with socio-economic 150 assessment $(\mathrm{Re}, 2015)$ was performed in the Grombalia plain (N-E Tunisia) targeted to a complete nitrate 151 vulnerability assessment of the region. The sampling campaign combined the typical activities of a 152 groundwater quality monitoring, together with a structured social analysis performed by the research team 153 while conducting the field works.

\subsection{Hydrogeochemical investigation}

156 Between February and March 2014 (i.e. at the end of the rainy season/winter) a total of 51 groundwater 157 samples were collected in both the shallow (depth generally $<50 \mathrm{~m}$ ) and deep Grombalia (depth generally > $15850 \mathrm{~m}$ ) aquifers (26 and 25 respectively). Samples were collected from private hand-dug wells, mostly 159 equipped with electrical pump, and from both private and public boreholes.

160 The sampling strategy took into account the historical sampling network and the previous studies in the 161 region (Ben Moussa et al., 2010; Ben Moussa and Zouari, 2011; Ben Moussa et al., 2012; Charfi et al., 162 2013). This favoured the design of the sampling network presented in Figure 2, covering the whole Grombalia 163 Basin and including the sites potentially more susceptible to nitrate contamination.

164 In situ measurements of electrical conductivity, $\mathrm{pH}$ and water temperature (Table X1 - Supplementary 165 Materials) were performed, using a WTW 340i multimeter. Samples for major ion analysis were filtered 166 through $0.45 \mu \mathrm{m}$ cellulose membrane and stored in high density polyethylene bottles. Chemical and isotopic 167 analyses of the water samples were performed at the Laboratory of Radio-Analyses and Environment (LRAE) 168 of the National School of Engineers of Sfax (Tunisia). Major elements were analysed using a Dionex DX 100 
169 ion chromatograph equipped with a CS12 and an AS14A-SC Ion Pac columns and an AS-40 auto- sampler. 170 The total alkalinity $\left(\right.$ as $\left.\mathrm{HCO}_{3}{ }^{-}\right)$was determined by titration with standard hydrochloric acid $(0.1 \mathrm{~N})$ using methyl 171 orange and phenolphthalein as indicators. The error, based on the charge balance, was calculated to be $172<5 \%$. The isotopes of dissolved nitrate $\left(\delta^{15} \mathrm{~N}_{\mathrm{NO} 3}\right.$ and $\left.\delta^{18} \mathrm{O}_{\mathrm{NO}}\right)$ were prepared and analysed at the ISO4 private 173 laboratory (Turin, Italy) using a Finningan ${ }^{\text {TM }}$ MAT 250 Mass Spectrometer, following the procedures 174 described by Silva et al. (2000). Results are expressed in \%o and refer to AIR and V-SMOW (Gonfiantini et 175 al., 1995) with uncertainties $(2 \sigma)$ of $\pm 0.5 \%$ and $\pm 1 \%$ respectively.

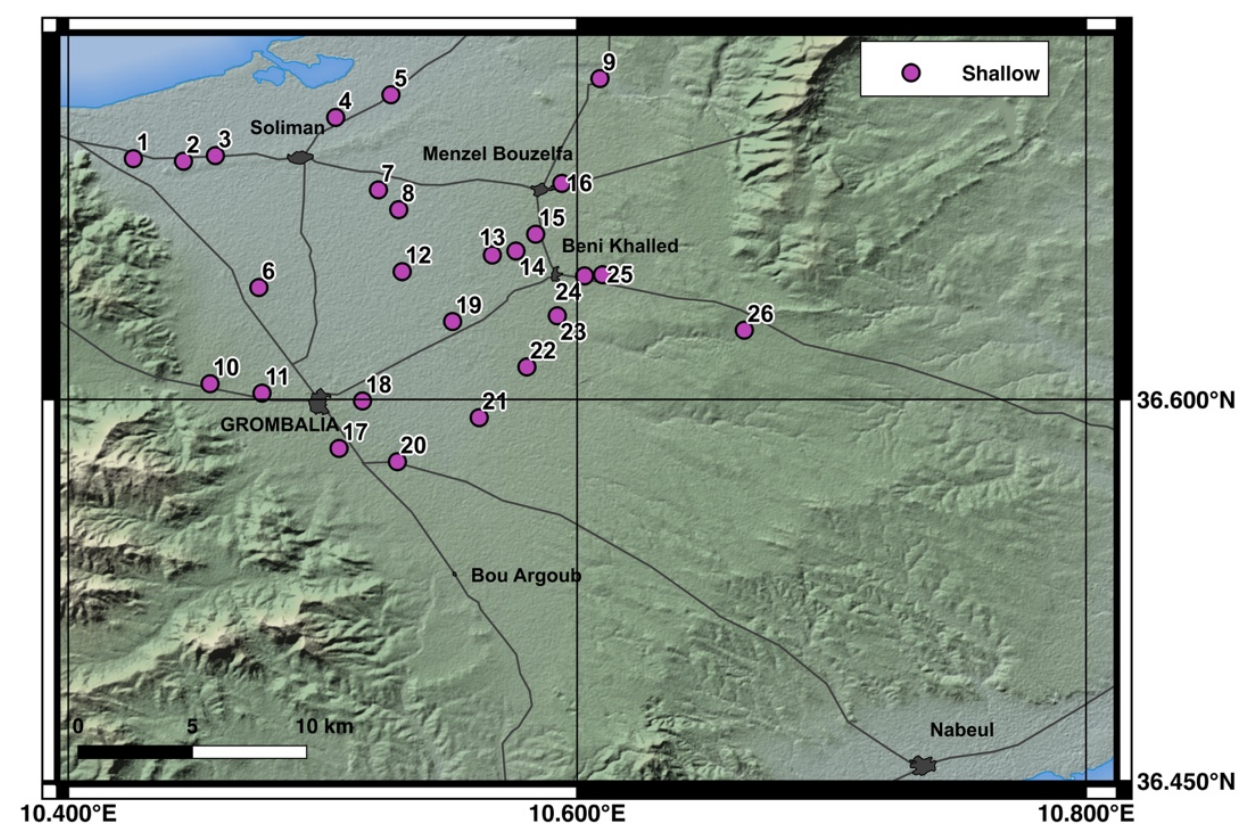

A

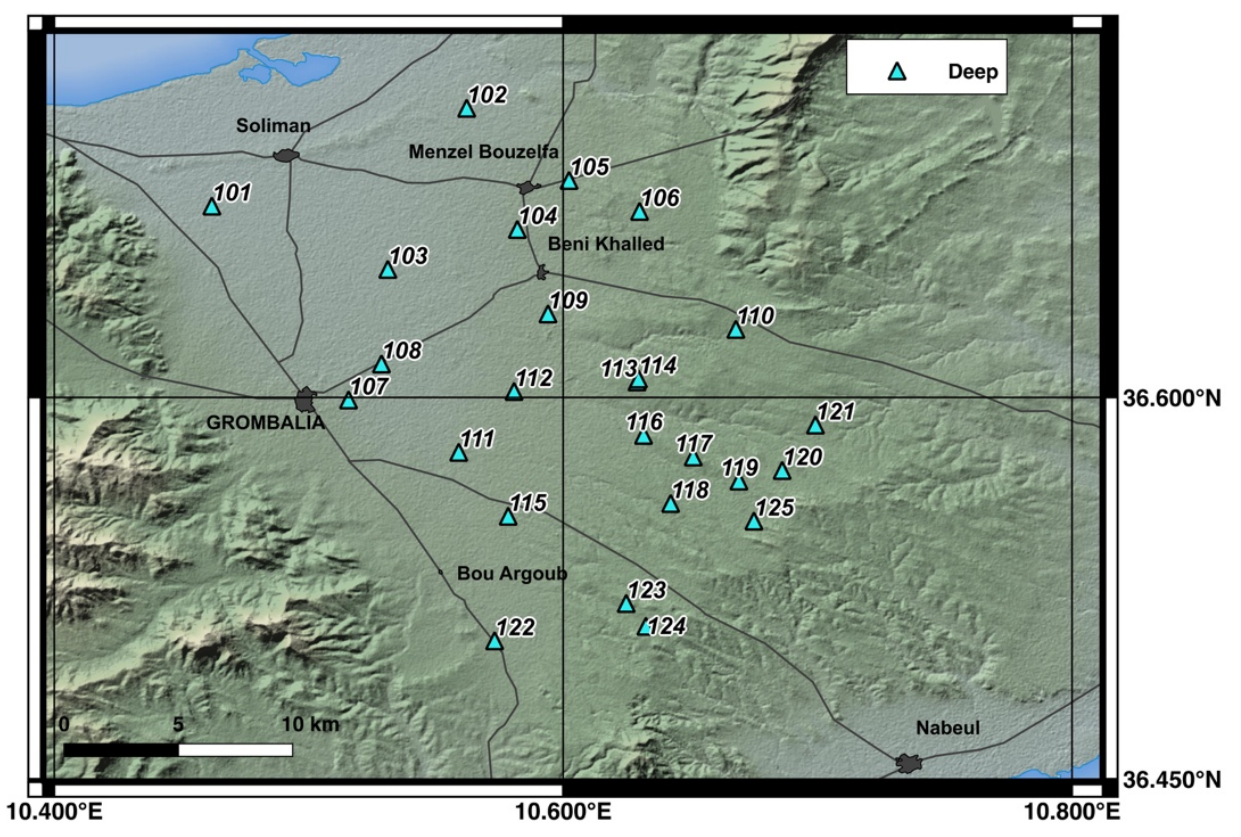

B 
Figure 2. Location of the sampling sites: (A) shallow aquifer; (B) deep aquifer.

\section{3.2. Socio-hydrogeological approach}

178 The socio-hydrogeological approach proposed by $\operatorname{Re}(2015)$ combines the groundwater quality assessment with capacity building and participatory activities, and it is cantered on the role of hydrogeologists as advocates for public engagement in water management and governance.

181 Therefore, during the previously described field work performed, all the farmers and well owners of the 51

182 sampled sites were asked to respond to structured interviews on water use and agricultural practices (Tringali 183 et al., 2017). The main goal of this activity was to create a momentum for dialogue on local groundwater 184 protection and capacity building, while also collecting relevant information on groundwater use and pollution 185 issues. The interviews were administered directly by the research team and were focused on the collection of 186 information related to sampled wells' features, groundwater uses and perceived anthropogenic impacts on water resources, crop production, irrigation and fertilizer use (Re, 2015; Table 1).

Table 1. Summary of the structure and information retrieved with the structured questionnaires proposed by Re (2015).

\begin{tabular}{lll}
\hline Part & Goal & Information \\
\hline $\begin{array}{l}\text { Personal } \\
\text { information }\end{array}$ & $\begin{array}{l}\text { Obtain information (to be treated anonymously) } \\
\text { on the rural population features }\end{array}$ & Gender, age, education, occupation, contacts \\
\hline Water use & $\begin{array}{l}\text { Retrieve information on regional and local } \\
\text { characteristics to support data interpretation }\end{array}$ & $\begin{array}{l}\text { Well features (age, depth, main characteristics), } \\
\text { groundwater withdrawal rates, groundwater use trends, } \\
\text { perceived or ascertained groundwater quality issues }\end{array}$ \\
\hline $\begin{array}{l}\text { Purposes of } \\
\text { groundwater uses }\end{array}$ & $\begin{array}{l}\text { Obtain information on local activities and } \\
\text { priorities to support data interpretation }\end{array}$ & $\begin{array}{l}\text { Groundwater use, kinds of crops cultivated, seasonal } \\
\text { production, kinds and quantity of fertilizers used, } \\
\text { irrigation type }\end{array}$ \\
\hline $\begin{array}{l}\text { Awareness of } \\
\text { water issues }\end{array}$ & $\begin{array}{l}\text { Know farmers and well holders perception } \\
\text { about water issues }\end{array}$ & $\begin{array}{l}\text { Perception of: water scarcity, climate change, integrated } \\
\text { water resources management and groundwater pollution }\end{array}$ \\
\hline $\begin{array}{l}\text { Potential for } \\
\text { Participation }\end{array}$ & $\begin{array}{l}\text { Evaluation of the potential for the } \\
\text { implementation of participatory monitoring and } \\
\text { management initiatives }\end{array}$ & $\begin{array}{l}\text { Farmers' role in groundwater protection, perceived } \\
\text { groundwater issues in the region, perception of scientists } \\
\text { and policy makers regarding local groundwater } \\
\text { management, willingness to be included in the } \\
\text { groundwater monitoring network }\end{array}$ \\
\hline
\end{tabular}

\section{Results and discussion}

\section{4.1. Hydrogeochemical characteristics of the Grombalia aquifer}

194 The high salinity recorded in the shallow aquifer has been pointed out by different authors, highlighting that 195 mineralization processes in the region are relevant (Charfi et al., 2013) and concern areas where farming and 196 agricultural activities are more intensive. The abundance of dissolved salts, especially of nitrates, chlorides 197 and sulphates, indicates an alteration of physical-chemical properties due to anthropogenic activities (Ben 198 Moussa and Zouari, 2011; Ben Moussa et al., 2014), thus constituting a serious threat for public health and 199 crop production. Indeed, in their study on the unconfined aquifer, Tlili-Zrelli et al. (2013) indicate that all 200 groundwater samples exceeded the drinking water limits for $\mathrm{Na}, \mathrm{Cl}$ and $\mathrm{SO} 4$, whereas $70 \%$ of the samples 
exceeded also that for $\mathrm{Ca}$ and $\mathrm{Mg}$, imparting strong limitations on the use of groundwater for irrigation purposes.

203 Although numerous authors have investigated groundwater quality from the shallow aquifer, little is known 204 about the composition of the deep groundwater and the factors regulating its chemistry. Our work therefore 205 focused on the comparison between these two aquifer layers.

206 Samples collected in our study show Electrical conductivity ranges from 1.04 to $9.18 \mathrm{mS} / \mathrm{cm}$ (mean 3.87 $\mathrm{mS} / \mathrm{cm}$ ) in the shallow aquifer and from 1.04 to $7.13 \mathrm{mS} / \mathrm{cm}$ (mean $2.37 \mathrm{mS} / \mathrm{cm}$ ) in the deep one (Table X1 Supplementary Materials and Table 2). Chloride concentrations range from $112.4 \mathrm{mg} / \mathrm{L}$ (well 18), to 2932.4 $\mathrm{mg} / \mathrm{L}$ (well 1), with average of $838.8 \mathrm{mg} / \mathrm{L}$, in the phreatic aquifer, and from $107.3 \mathrm{mg} / \mathrm{L}$ (well 122) to 3436 $\mathrm{mg} / \mathrm{L}$ (well 108), with average of $473.3 \mathrm{mg} / \mathrm{L}$ in the deep one. This confirms the high mineralization of the studied system for both the shallow and deep aquifer.

Table 2. Descriptive statistics and Mann-Whitney $U$ test results. Concentrations are expressed in $\mathrm{mg} / \mathrm{L}$, while isotopic values as permil. Underlined values correspond to not-statistically significant parameters. Values in bold indicate the group with the highest mean ranks relative to each statistically significant parameter.

\begin{tabular}{|c|c|c|c|c|c|c|c|c|c|c|c|c|c|c|c|c|}
\hline & & EC & $\mathrm{pH}$ & $\mathrm{HCO}_{3}^{-}$ & $\mathrm{CO}_{3}^{-}$ & $\mathrm{SO}_{4}^{-}$ & $\mathrm{Cl}^{\circ}$ & $\mathrm{NO}_{3}^{-}$ & $\mathrm{Ca}^{++}$ & $\mathrm{Mg}^{++}$ & $\mathrm{Na}^{+}$ & $\mathrm{K}^{+}$ & $\delta^{18} 0$ & $\delta^{2} \mathrm{H}$ & $\delta^{15} \mathrm{~N}$ & $\delta^{18} O_{\text {NO3 }}$ \\
\hline \multirow[t]{4}{*}{ Shallow } & Min. & 1.0 & 6.9 & 164.7 & 0.0 & 145.3 & 112.4 & 0.0 & 69.0 & 26.1 & 111.1 & 0.0 & -5.4 & -37.1 & 4.6 & 7.8 \\
\hline & Average & 3.9 & 7.2 & 332.5 & 0.0 & 434.1 & 838.8 & 148.0 & 349.5 & 99.9 & 397.5 & 16.8 & -4.6 & -28.4 & 10.8 & 12.8 \\
\hline & Std. Dev & 1.5 & 0.2 & 75.8 & 0.0 & 165.0 & 534.1 & 140.9 & 156.8 & 54.2 & 220.0 & 10.7 & 0.5 & 3.2 & 5.3 & 4.4 \\
\hline & $\begin{array}{l}\text { Mean M-W } \\
\text { Rank }\end{array}$ & 33.7 & 23.5 & 27.8 & 23.5 & 34.2 & 34.4 & 31.6 & 34.8 & 31.7 & 32.7 & 28.6 & 34.9 & 33.9 & 11.6 & 10.6 \\
\hline \multirow[t]{7}{*}{ Deep } & Min. & 1.0 & 7.0 & 128.1 & 0.0 & 23.8 & 107.3 & 2.0 & 31.6 & 12.7 & 72.8 & 4.2 & -6.1 & -34.8 & 4.9 & 7.9 \\
\hline & Max. & 7.1 & 7.7 & 688.0 & 42.0 & 3105.0 & 3436.0 & 230.6 & 696.5 & 557.3 & 1888.4 & 63.6 & -4.5 & -28.7 & 11.6 & 12.7 \\
\hline & Average & 2.4 & 7.3 & 321.3 & 4.8 & 383.0 & 473.3 & 55.7 & 181.8 & 89.7 & 275.9 & 16.1 & -5.4 & -31.8 & 8.1 & 10.7 \\
\hline & Std. Dev & 1.4 & 0.2 & 99.9 & 11.1 & 777.1 & 650.6 & 62.1 & 157.6 & 114.0 & 359.0 & 15.0 & 0.4 & 1.7 & 2.0 & 1.6 \\
\hline & $\begin{array}{l}\text { Mean M-W } \\
\text { Rank }\end{array}$ & 18.0 & 28.6 & 24.1 & 28.6 & 17.4 & 17.3 & 20.2 & 16.9 & 20.0 & 19.0 & 23.3 & 15.4 & 16.4 & 7.8 & 9.3 \\
\hline & $\begin{array}{l}\text { Mann- } \\
\text { Whitney U }\end{array}$ & 125.0 & 260.5 & 277.5 & 260.0 & 111.0 & 108.0 & 179.0 & 97.0 & 176.0 & 150.0 & $\underline{258.0}$ & 69.0 & 93.0 & 26.0 & 38.0 \\
\hline & $p$ value & 0.0 & 0.2 & 0.4 & 0.0 & 0.0 & 0.0 & 0.0 & 0.0 & 0.0 & 0.0 & 0.2 & 0.0 & 0.0 & 0.1 & 0.6 \\
\hline
\end{tabular}

218 A Piper diagram, plotted in rectangular coordinates (Ray and Mukherjee, 2008) was used to highlight the 219 different groundwater facies in the studied area. Nitrate concentrations were taken into account for the plot, 220 due to its abundance in both the shallow and deep aquifers (Table X1 - Supplementary Materials). Grombalia 221 groundwater can be generally classified as $\mathrm{Ca}(\mathrm{Mg})-\mathrm{SO}_{4}\left(\mathrm{Cl}+\mathrm{NO}_{3}\right)$ water type (Figure 3). Only some samples 222 from the deep aquifer $(102,103,107,112)$ display a $\mathrm{Na}-\mathrm{SO}_{4}\left(\mathrm{Cl}+\mathrm{NO}_{3}\right)$ facies, while for others $(110,113,119$ 223 and 122) bicarbonate is the dominant anion. From this diagram, no clear differences in water types between 
the shallow and the deep aquifer appear; only the composition of deep groundwater seems slightly more variable than that of the shallow.

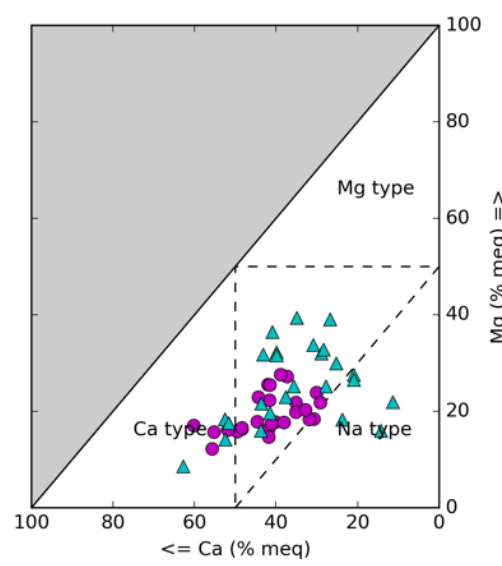

226

227

228

229

230

231

232

233

234

235

236 value $>0.05$ ).

Box plots comparing the major ion contents in groundwater from the two aquifers are reported in Figure 4.

Figure 3. Piper diagram in rectangular coordinates (Modif. After Ray and Mukherjee, 2008) for the samples collected between February and March 2014 in the shallow and deep Grombalia aquifers.

Accordingly, the shallow aquifer displays higher contents in dissolved cations and anions, with the highest differences observed for nitrate, chloride, sulphate and calcium contents, while the distribution of the other ions is rather similar. This evidence is also supported by the Mann - Whitney $U$ test (Table 2) highlighting that only for $\mathrm{pH}, \mathrm{HCO}_{3}, \mathrm{~K}, \delta^{15} \mathrm{~N}_{\mathrm{NO} 3}$ and $\delta^{18} \mathrm{O}_{\mathrm{NO} 3}$ the two aquifers do not show statistically significant differences $(\mathrm{p}$

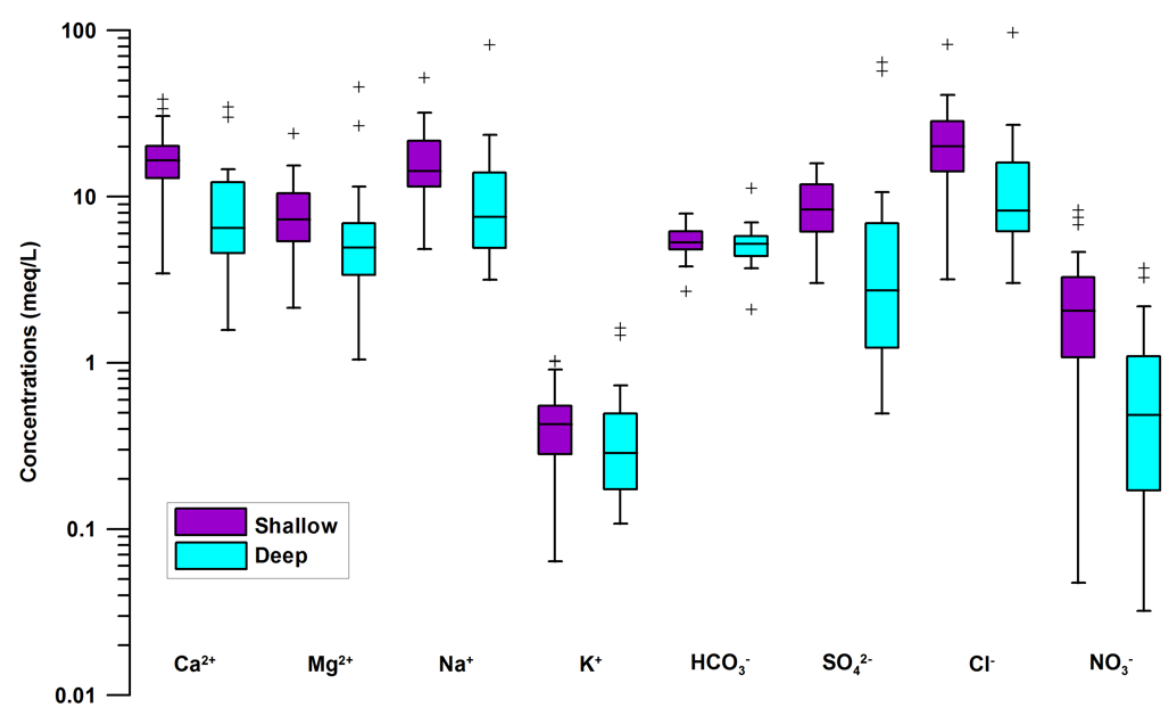

Figure 4. Box plots of the major ion contents for the shallow and deep aquifers in the Grombalia basin. 
240 Previous studies (e.g. Ben Moussa et al., 2010), based on ion ratios and saturation indexes, indicated that 241 the origin of mineralization is mostly from the dissolution of evaporites from the aquifer matrix, namely halite 242 and gypsum, whereas the high Ca excess, not balanced by sulphate ions, is due to cation exchange 243 processes (aquifer salinization).

244
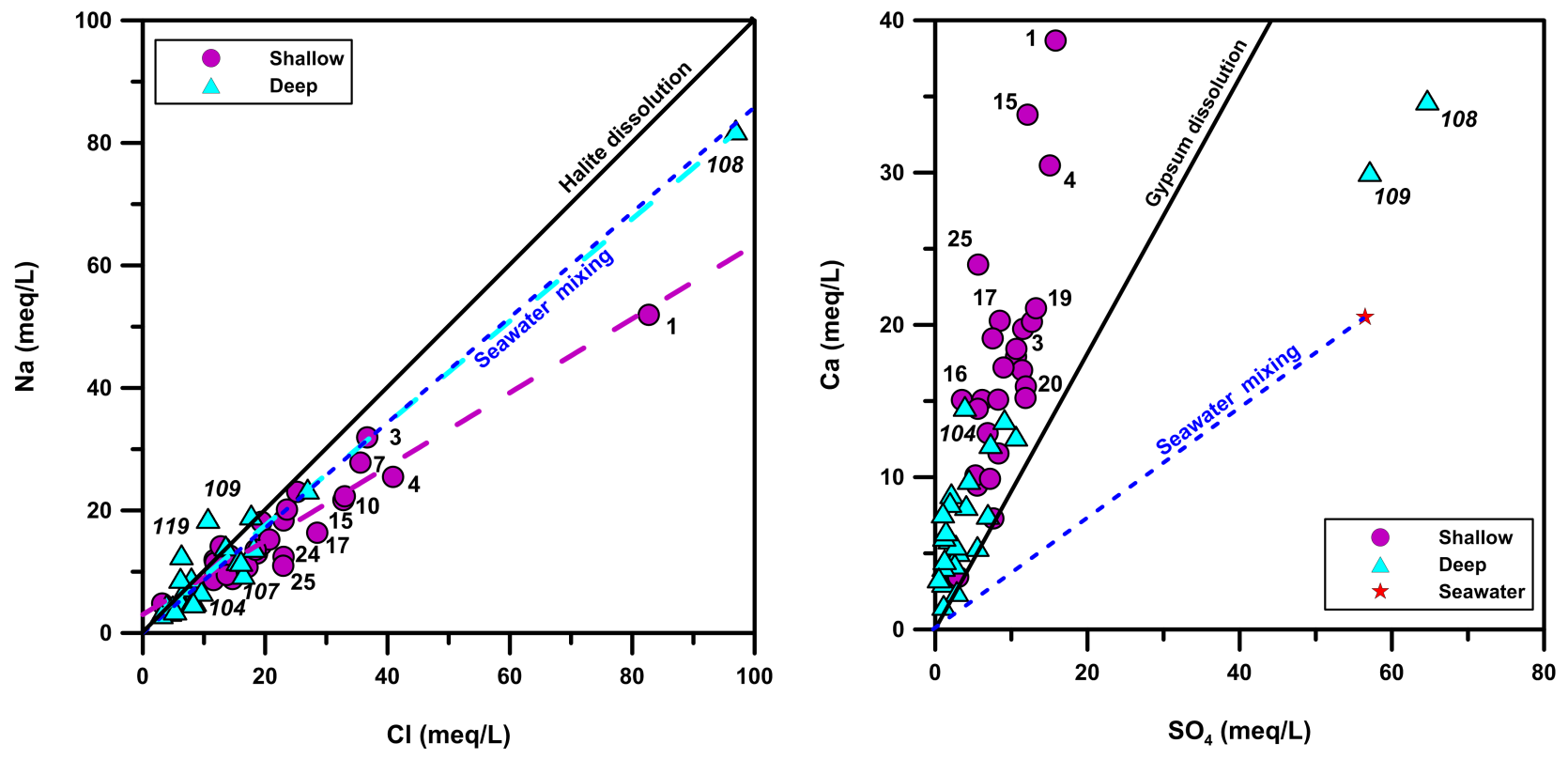

A

B

Figure 5. (A) Plot of $\mathrm{Na} v \mathrm{Cl}$ and (B) $\mathrm{Ca}$ vs $\mathrm{SO}_{4}$. Dashed blue line: Seawater mixing trend; Purple and cyan dashed lines correspond to the regressions for the shallow and deep aquifers respectively $\left(\mathrm{Na}=0.6036^{*} \mathrm{Cl}+3.0061, \mathrm{R}^{2}=0.903\right.$ and $\mathrm{Na}=0.8342 * \mathrm{Cl}+0.8607$,

$247 \quad \mathbf{R}^{2}=\mathbf{0 . 9 6 2 )}$.

248

249

250

251

252

253

254

255

256

257

258

259

260

261

262

263

In the $\mathrm{Na}$ versus $\mathrm{Cl}$ plot (Figure 5A), samples from the shallow aquifer align following the equation $\mathrm{Na}=$ $0.6036^{*} \mathrm{Cl}+3.0061\left(R^{2}=0.903\right)$ which does not correspond exactly to the $1: 1$ line expected for halite dissolution but shows an excess in $\mathrm{Cl}$ (or a deficiency in $\mathrm{Na}$ ). Another source of $\mathrm{Na}$ and $\mathrm{Cl}$ could also be considered, i.e. sea water, but even in this case several samples (e.g. 7, 4, 10, 15, 17, 24, 25) plot below the seawater mixing line. Samples from the deep aquifer have a different behavior, and tend to align more clearly on both the halite dissolution and seawater mixing lines $\left(\mathrm{Na}=0.8342^{*} \mathrm{Cl}+0.8607 ; \mathrm{R}^{2}=0.962\right)$, with the more saline sample (108) plotting directly on the latter, and two samples (109 and 119) with an excess in $\mathrm{Na}$, plotting above the two previously mentioned lines. Also in the $\mathrm{Ca}$ vs $\mathrm{SO}_{4}$ plot (Figure $5 \mathrm{~B}$ ) samples do not align on the 1:1 line, indicative of gypsum dissolution, but show an excess in Ca for both the shallow and the deep aquifers. Two deep samples instead (108 and 109) plot close to the seawater composition. This excess in $\mathrm{Ca}$, according to previous interpretations, is due to cation exchanges, which sequester $\mathrm{Na}$ and release $\mathrm{Ca}$ in solution. This process can be evidenced in the plot of $(\mathrm{Na}+\mathrm{K})-\mathrm{Cl}$ versus $(\mathrm{Ca}+\mathrm{Mg})-\left(\mathrm{HCO}_{3}+\mathrm{SO}_{4}\right)$ (Figure 6) where samples should align on a -1 slope line (McLean et al., 2000). Indeed, for our case study, samples from the shallow aquifer are aligned and fall in the field of aquifer salinization (i.e. Na uptake and Ca release) but with a higher slope $(-1.27)$, suggesting that other processes should be considered to account for 
mineralization. Samples from the deep aquifer are more in agreement with the aquifer salinization interpretation (i.e. fall on a -1 slope), although some samples $(108,109$ and 119) deviate from this trend.

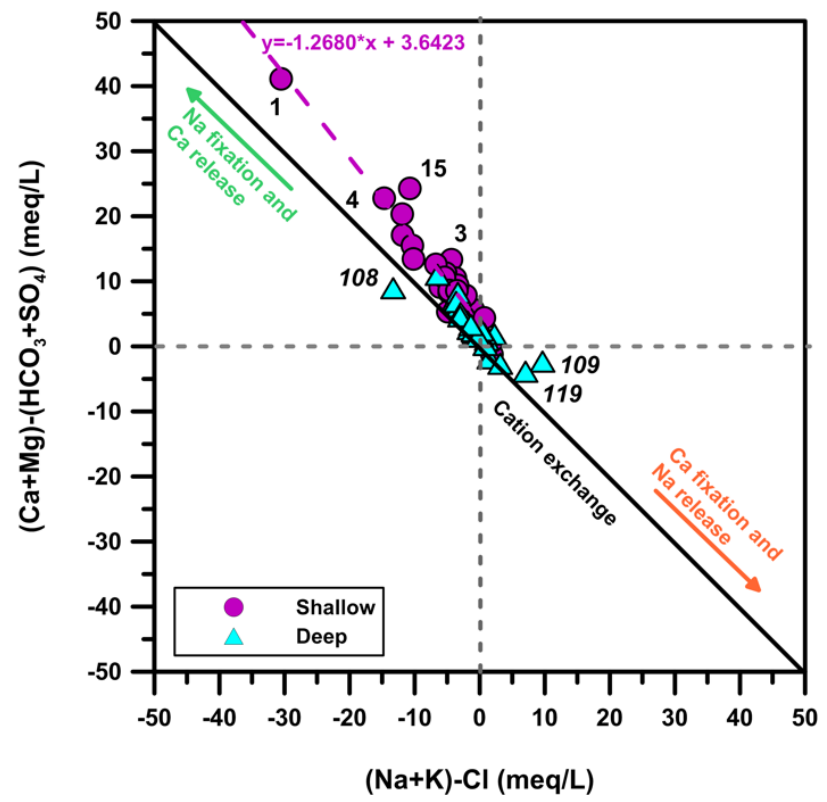

(Na+K)-Cl (meq/L)

Figure 6. ( $\mathrm{Na}+\mathrm{K})-\mathrm{Cl}$ versus (Ca+Mg)-(HCO3+SO4). Black line: cation exchange (-1: 1) line.

In conclusion, the processes regulating groundwater chemistry in the shallow and in the deep aquifers show similarities (salinity and hydrochemical facies) but also differences (some lower ionic content for the deep aquifer). A full understanding of water-rock interaction for these waters would require geochemical modelling and is out of the scope of this paper. Nevertheless, it should be noted that the most mineralized waters form the shallow aquifer are located along the coast in the industrial area around Soliman: here groundwater overexploitation could have induced sea water intrusion and associated aquifer salinization processes, which modify the $\mathrm{Ca} / \mathrm{Na}$ ratio. On the other hand, the highest mineralization in the deep aquifer is observed for wells 108 and 109, and is mostly due to the abundance of sulphate ions in solution. These samples are located at more than $15 \mathrm{~km}$ inland in an area between Beni Khalled and Grombalia, corresponding to an area where Tlili-Zrelli et al. (2013) already evidenced elevated sulphate contents not associated to Ca in groundwater. Hence, another source of salinity should be considered, of more continental origin and located at depth (e.g. evaporites containing MgSO4).

\subsection{Nitrate contamination}

High nitrate concentrations in the shallow aquifer have been remarked over the years by different authors (e.g. Ben Moussa and Zouari, 2011; Charfi et al., 2013, Kammoun et al., submitted), and are confirmed by our survey. In the $\mathrm{NO}_{3}{ }^{-}$distribution map (Figure 7), only few shallow wells (1, 7, 12, 18, 19, 20 and 21) show concentrations below the drinking water statutory limits of $50 \mathrm{mg} / \mathrm{L}$ (WHO, 2011), while most of the samples 
are not suitable for human consumption, with concentrations ranging from $67 \mathrm{mg} / \mathrm{l}$ (well 23) to $515 \mathrm{mg} / \mathrm{L}$ (well 290 15). Two pollution "hotspots" can be identified. The first is located in the central part of the plain (well 15 and 291 surroundings), an area identified by Chenini et al. (2015) as high to very high groundwater contamination risk, 292 due to the dominance of irrigated areas. This evidence would support the proposed strong contribution of 293 agricultural activities to nitrate contamination, enhanced by long-term flood irrigation practices.

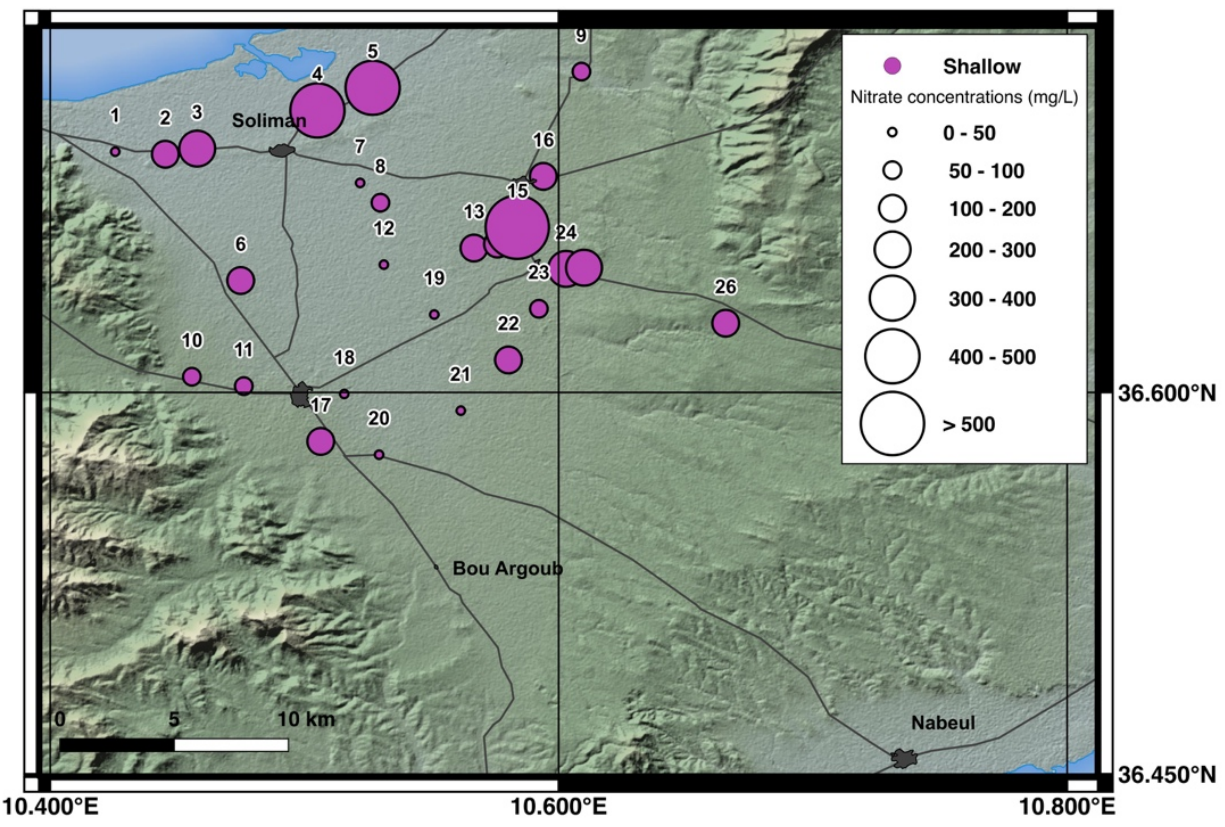

A

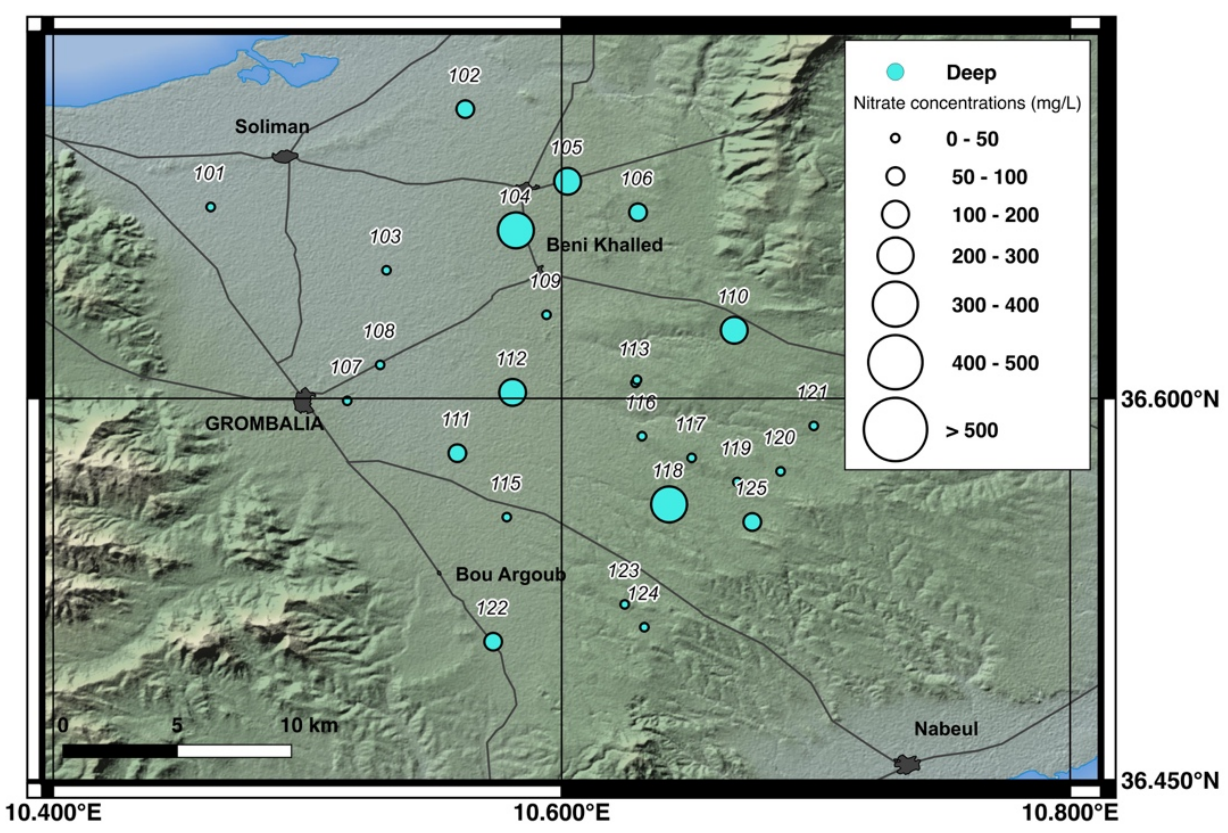

B

295 Figure 7. Nitrate concentration distribution map in the Grombalia Basin: (A) shallow aquifer, (B) deep aquifer. 
On the other hand, the second pollution hotspot is located along the coast (e.g. wells 4 and 5), where urban settlements and industrial activities dominate the land use (Chenini et al., 2015), testifying for the presence of multiple nitrate sources in the investigated area. Concerning the deep aquifers samples, 15 out of 25 can be considered suitable for drinking purposes, whereas in the others $\mathrm{NO}_{3}{ }^{-}$concentrations range from $55 \mathrm{mg} / \mathrm{L}$ (well 111) to 231 (well 118): these values, although significantly lower than those found in the phreatic aquifer, indicate that the deep aquifer may be severely impacted by nitrate pollution as well. Also in this case, the highest concentrations are recorded in the cultivated area (sample 104), but also closer to the recharge area to both aquifers (sample 118).

Another common feature to both aquifers is the presence of an area where nitrate contents are relatively low, located between the cities of Grombalia and Beni Kalled, the first identified pollution hotspot. In order to explain such low concentrations, Charfi et al. (2013) suggested the possible presence of denitrification processes.

The isotopic investigation was undertaken to identify the nitrate pollution sources and the processes affecting their concentration. The isotopic compositions of dissolved nitrates range between +4.65 and $+25.38 \%$ vs AIR in $\delta^{15} \mathrm{~N}_{\mathrm{NO} 3}$ and between +7.8 and $+19.4 \%$ vs SMOW in $\delta^{18} \mathrm{O}_{\mathrm{NO} 3}$ in the shallow aquifer, and between +4.90 and $+11.65 \%$ vs AIR in $\delta^{15} \mathrm{~N}_{\mathrm{NO} 3}$ and between +7.9 and $+12.7 \%$ vs SMOW in $\delta^{18} \mathrm{O}_{\mathrm{NO} 3}$ in the deep 312 aquifer.

313 In order to identify the dominant sources, samples were plotted in a diagram displaying the $\mathrm{NO}_{3}{ }^{-}$ concentration vs $\delta^{15} \mathrm{~N}_{\mathrm{NO}}$ (Figure $8 \mathrm{~A}$ ) together with the normal ranges reported in the literature for each source. Even in this case, no significant differences can be observed for the shallow and the deep aquifer.

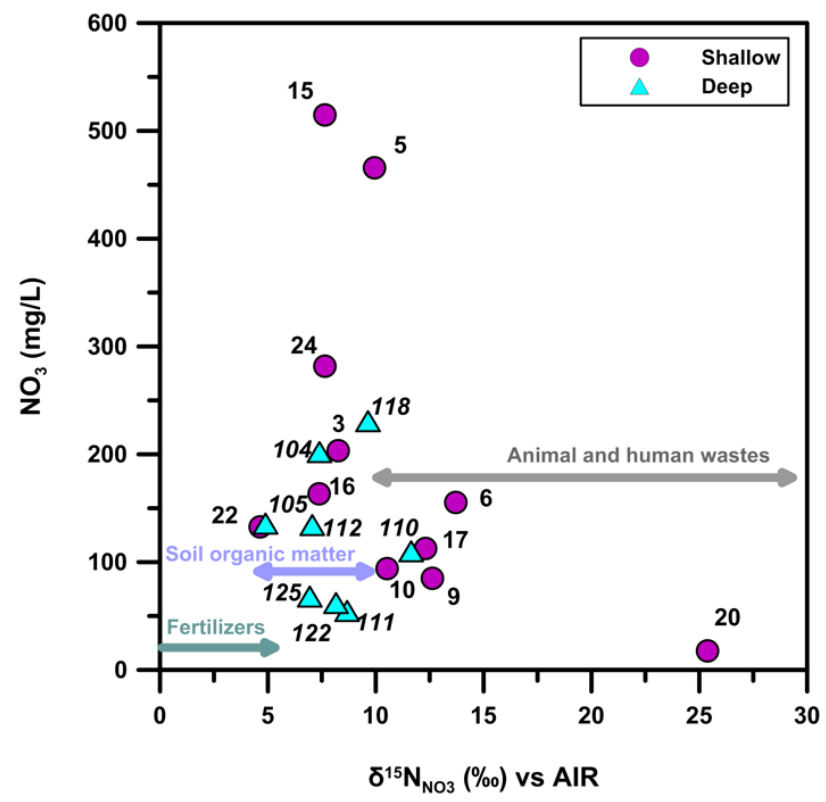

A

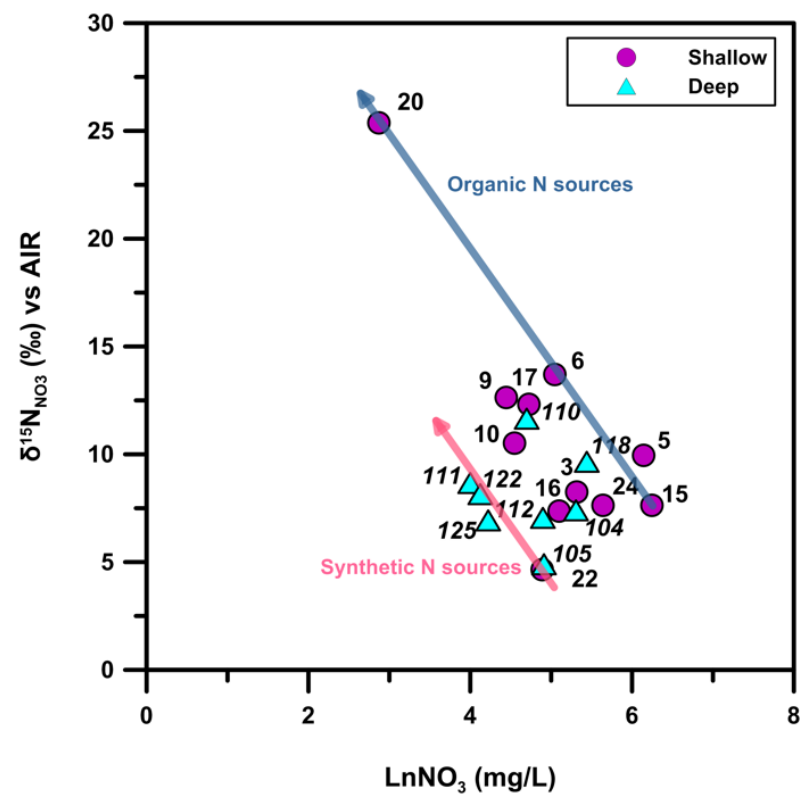

B

Figure 8. (A) Nitrate concentration vs $\delta^{15} \mathrm{~N}$. The reported ranges for nitrogen pollution sources are based on Clark 318 and Fritz, 1997). (B) $\delta^{15} \mathrm{~N}$ s InNO $\mathrm{N}_{3}$, with the possible denitrification trends identified for synthetic (red arrow) and 319 organic (blue arrow) nitrogen sources. 
320 Some groundwater samples $(22,105)$ fall close to the compositional range of synthetic fertilizers, although 321 their nitrogen isotopic composition is rather enriched, since fertilizers generally range between $-4 \%$ and $+4 \%$ 322 in $\delta^{15} \mathrm{~N}_{\mathrm{NO} 3}$ (Kendall et al., 2007). Nevertheless, the original isotopic composition of fertilizers can be enriched 323 by other processes occurring in the soil prior to be leached to groundwater, namely volatilization, which is 324 enhanced in alkaline soils and arid climates (Kendall et al., 2007). Similar isotopic compositions for 325 groundwater nitrates are reported for the Bou Areg plain in Morocco by Re and Sacchi (2017, and references 326 therein), and attributed by the authors to synthetic fertilizers enriched by different degrees of ammonia 327 volatilization.

328 Most of the samples display an $\delta^{15} \mathrm{~N}_{\mathrm{NO} 3}$ in the compositional range of soil organic matter. Nevertheless, since 329 nitrate concentrations largely exceed the expected natural background level, (10-12 mg/L; Shand and 330 Edmunds, 2008; Sacchi et al., 2013) these samples likely record a mixed contamination from both synthetic 331 fertilizers and anthropogenic organic matter (animal or human waste). The latter source is characterized by 332 enriched $\delta^{15} \mathrm{~N}_{\mathrm{NO} 3}$ values, exceeding $+10 \%$; nevertheless, we considered this organic matter contribution 333 dominant for samples showing a $\delta^{15} \mathrm{~N}_{\mathrm{NO} 3}$ greater than $+8.6 \%$ (Re and Sacchi, 2017). It should be noted that 334 the most enriched sample in $\delta^{15} \mathrm{~N}_{\mathrm{NO} 3}$ also displays a low nitrate concentration, which could be due to 335 denitrification processes.

336 Indeed, when plotting $\delta^{15} \mathrm{~N}_{\mathrm{NO} 3}$ vs $\operatorname{InNO}_{3}{ }^{-}$(Figure $8 \mathrm{~B}$ ), samples affected by denitrification should plot on a 337 straight line. Two of such trends can be identified in the plot: one, mostly displayed by samples from the 338 shallow aquifer $(15,5,6,20)$, originates from rather enriched isotopic compositions and therefore would 339 indicate the denitrification path followed by samples contaminated by organic matter sources. The second 340 trend with the same slope, mostly displayed by samples from the deep aquifer $(105,125,122,111)$ originates 341 from isotopic compositions in the range of synthetic fertilizers. Samples in between the two trends would 342 represent a mixture of these two dominant sources with variable degrees of enrichment due to denitrification.

343 The slope of the two identified trends corresponds to that indicated for a fractionation factor $\varepsilon$ of about $10 \%$ 344 (Kendall et al., 2007). In this case, the isotopic enrichment would be due to the denitrification of about 30 $34545 \%$ of the original nitrate content, reaching up to $80 \%$ in the case of sample 20 . This sample is located in the 346 previously mentioned area of low groundwater nitrate concentrations, despite the presence of a very shallow 347 water table depth. Here, denitrification processes could be favored by the presence of clay rich vertisols 348 (Chenini et al., 2015).

349 To verify the abovementioned hypothesis, the $\mathrm{NO}_{3}^{-}$vs $\mathrm{Cl}^{-}$diagram was plotted taking into account the 350 localization of the samples in the Grombalia plain (Table X1 - Supplementary Materials). In this graph (Figure 3519 ) it is possible to notice a remarkable enrichment trend of nitrate and chloride concentrations, especially 352 characterizing the wells located in the peri-urban areas, confirming the relevance of anthropogenic pollution 353 associated to domestic activities. Only two wells (e.g. 7, 1), with low or absent nitrate concentrations, show a 354 significant enrichment in chloride concentration that can be associate to the occurrence of saline water 355 intrusion in the coastal area near Soliman. 
356 On the other hand, most of the wells located in the rural zones or in areas with no dominant land use (hence 357 classified as intermediate) relatively lower $\mathrm{NO}_{3}{ }^{-}$concentrations, corresponding to the previously identified 358 trend of synthetic fertilizers pollution origin. Based on this observation, rural areas seem to be relatively less 359 contaminated than peri-urban ones, although, the presence of most of the deep wells in these zones 360 highlights the high vulnerability to agricultural pollution also in the deeper parts of the aquifer (Figure 10).

361 To better understand the factors controlling nitrate contamination origin and evolution, the hydrogeochemical 362 results have been analysed taking into account the territorial reality at regional level, based on the outcomes 363 of the results of structured interviews performed during in situ measurements.

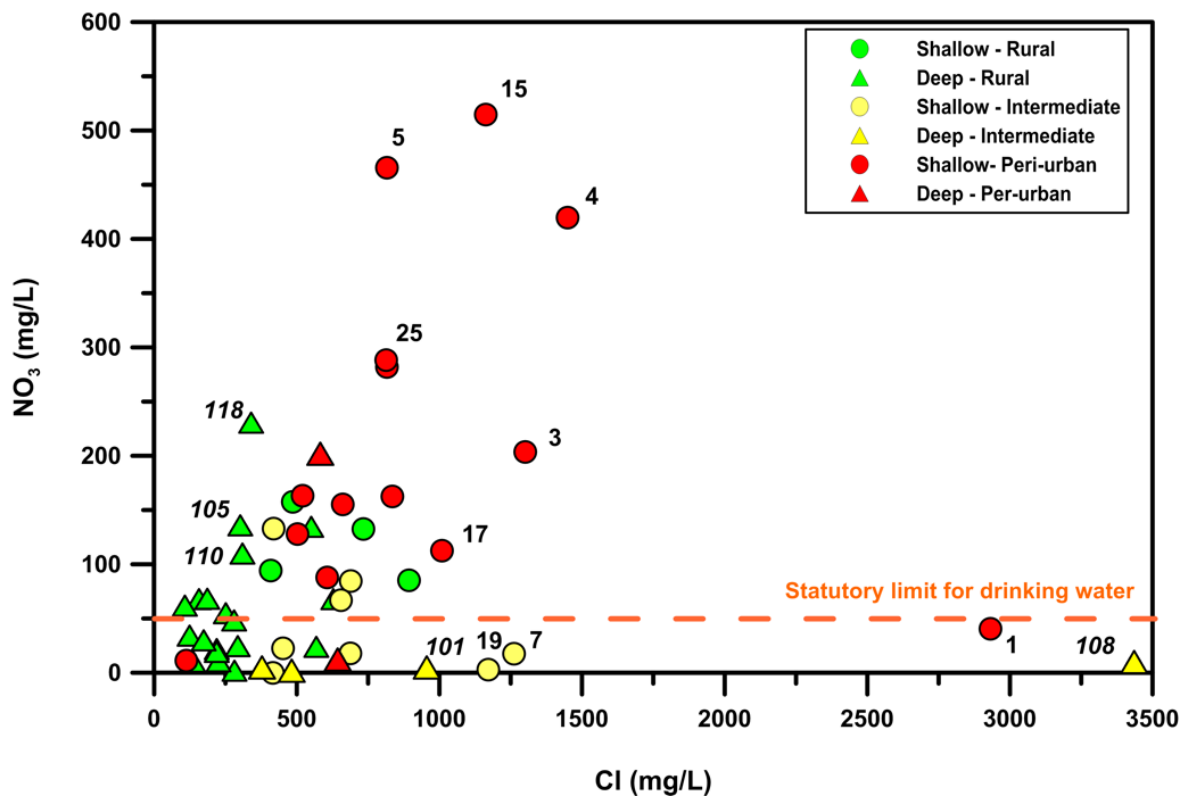

364 Figure 9. Nitrate versus chloride concentrations for the samples collected in the Grombalia Basin in the 365 February-March 2014 campaign. Orange dashed line: WHO (2011) statutory limit for drinking water (50 mg/L).

$\mathrm{NO}_{3}(\mathrm{mg} / \mathrm{L})$

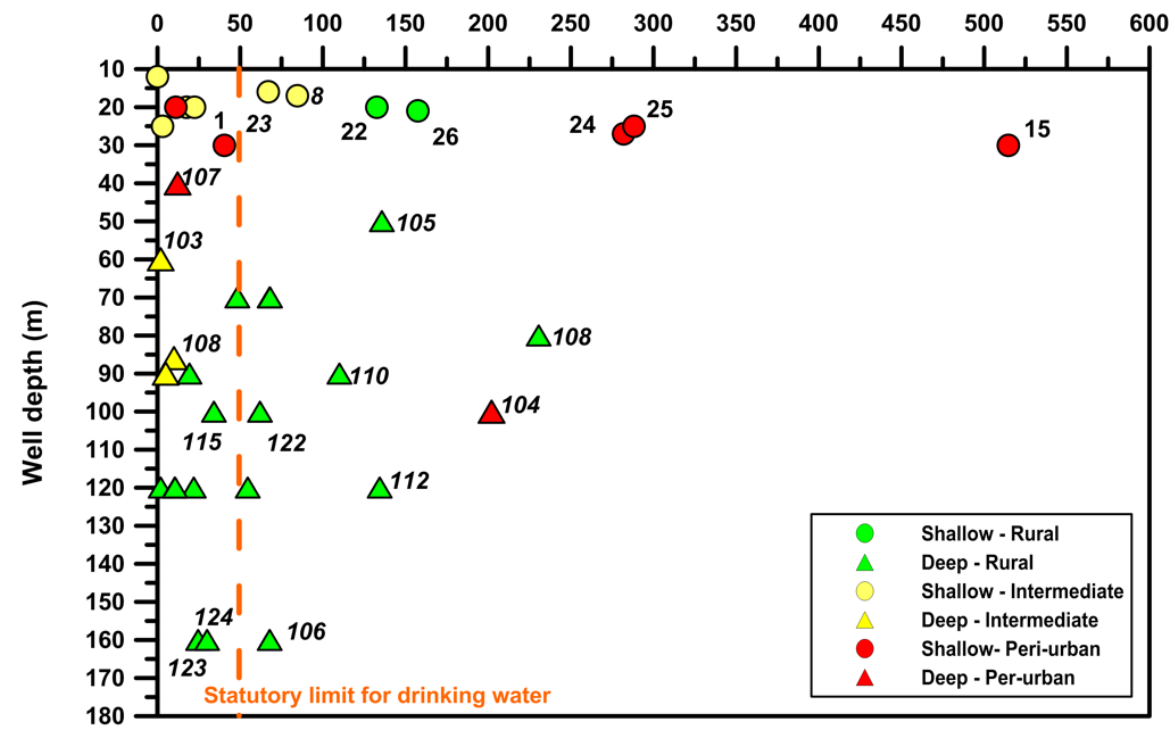

Figure 10. Nitrate concentrations versus well depth. 


\subsection{Socio-hydrogeological approach to identify nitrate pollution origin}

370 Field surveys were completed for $85 \%$ of the sampled sites $(78 \%$ of the shallow wells and $92 \%$ of the deep

371 ones; Table 3).

Table 3. Summary of the information retrieved with the structured interviews administered during the in situ measurements. Percentages indicated as "out of total" take into account that for some categories responses are higher to the number of respondents (i.e. corresponding to possibility to have multiple groundwater use and crop production in the same site).

\begin{tabular}{|c|c|c|}
\hline & Shallow & Deep \\
\hline Administered interviews & 21 & 23 \\
\hline Well owners & 6 & 10 \\
\hline Tenants & 15 & 13 \\
\hline \multicolumn{3}{|l|}{ Well type } \\
\hline Hand dug well & $23 \%$ & - \\
\hline Pumped well & $77 \%$ & $32 \%$ \\
\hline Borehole & - & $68 \%$ \\
\hline \multicolumn{3}{|l|}{ Irrigated area } \\
\hline Average & 2 hectares & 12 hectares \\
\hline Min. & 1 hectare & 1 hectare \\
\hline Max. & 4 hectares & 75 hectares \\
\hline \multicolumn{3}{|l|}{ Groundwater use (\% out of total) } \\
\hline Irrigation & $63 \%$ & $90 \%$ \\
\hline Domestic & $47 \%$ & $81 \%$ \\
\hline Drinking & $32 \%$ & $81 \%$ \\
\hline Animal husbandry & $5 \%$ & $38 \%$ \\
\hline \multicolumn{3}{|l|}{ Water type used for irrigation } \\
\hline Groundwater & $75 \%$ & $86 \%$ \\
\hline Groundwater and Irrigation channel water & $25 \%$ & $14 \%$ \\
\hline \multicolumn{3}{|l|}{ Irrigation type } \\
\hline Flood & $33 \%$ & - \\
\hline Drip & $54 \%$ & $89 \%$ \\
\hline Spray & - & - \\
\hline Mix (Flood-Drip/Spray-Drip) & $13 \%$ & $11 \%$ \\
\hline \multicolumn{3}{|l|}{ Crops (\% out of total) } \\
\hline Horticulture & $28 \%$ & $52 \%$ \\
\hline Arboriculture & $89 \%$ & $90 \%$ \\
\hline \multicolumn{3}{|l|}{ Fertilizers use } \\
\hline Manure & $16 \%$ & - \\
\hline Binary synthetic fertilizers (DAP) & - & $5 \%$ \\
\hline \multicolumn{3}{|l|}{ Three-component synthetic fertilizers (NPK) } \\
\hline Manure and NPK & $10 \%$ & $43 \%$ \\
\hline Manure, DAP and NPK & $37 \%$ & $19 \%$ \\
\hline \multirow[t]{2}{*}{ DAP and NPK } & $32 \%$ & $28 \%$ \\
\hline & $5 \%$ & $5 \%$ \\
\hline
\end{tabular}


378 Overall, well owners and farmers have shown high level of cooperation and interest in the outcomes of the 379 hydrogeological assessment, although few declined to respond to the interview but gave the permission to 380 collect groundwater samples in their property. The interviews confirmed that local people are generally aware 381 of the existence of groundwater issues in the region, and that they consider the most crucial problems to be: 382 (i) the aquifer salinity increase, (ii) the decrease in the piezometric level due to groundwater overexploitation, 383 and (iii) a clearly perceived degradation of water quality with respect to the previous years (Tringali et al., 384 2017). As a result of this high awareness, most of them expressed the willingness to be part of a collaborative 385 water management process to improve groundwater quality in the region.

386 Considering all the sampled sites, deep wells are used to irrigate larger agricultural parcels (up to 75 387 hectares; Table 3), probably due to the prevailing use of boreholes and resulting water availability. In fact, 388 almost all the wells sampled in the deep aquifer are used for irrigation, often with a multiple utilization that 389 includes drinking and domestic (i.e. household cleaning). The same groundwater use pattern can be 390 observed for the shallow wells, mainly providing water for irrigation, but in some cases also used for 391 household consumption, even though the high salinity makes people less inclined to its consumption for 392 drinking water purposes except when other sources are not available. As it emerged during the interviews, 393 local farmers are generally aware of groundwater salinity issues but have a scarce knowledge of the other 394 potential contamination sources. As a result, besides the environmental and crops' productivity implications of 395 using contaminated groundwater, many people are unaware of drinking water that is not so adequate for 396 human consumption, with potential severe consequences on their health in the long run. This is why, as part 397 of the proposed socio-hydrogeological approach, during interviews administration some time was also 398 dedicated to knowledge transfer to farmers and wells' owners, and particularly targeted to information sharing 399 on the general status of the studied aquifers and to raising awareness on the implication of groundwater 400 misuse and pollution (Tringali et al., 2017).

401 As previously mentioned (Section 4.2), most of the authors have attributed the high $\mathrm{NO}_{3}{ }^{-}$concentration in the 402 shallow aquifer to the impact agricultural return flow due to the fertilizers application rates and long-term flood 403 irrigation. However, of all the interviewees only $33 \%$ of the shallow well's holders (i.e. $16 \%$ of the total) still 404 uses flood irrigation in their fields, while the majority is opting for drip irrigation ( $78 \%$ of the total), generally 405 considered the most effective irrigation practice in arid and semi-arid regions. Apparently, this shift towards 406 more sustainable irrigation practices occurred in late 90s has had little influence on the nitrate contamination, 407 which is still increasing (Kammoun et al., submitted), suggesting long recovery times for the aquifers.

408 Finally, it is interesting to note that the farmers' majority indicated the use of manure, alone or in combination 409 with other types of synthetic fertilizers to increase crop production.

410 In order to identify the different sources of nitrate in the investigated area, the isotopic composition of nitrogen 411 and oxygen $\left(\delta^{15} \mathrm{~N}_{\mathrm{NO}}\right.$ versus $\left.\delta^{18} \mathrm{O}_{\mathrm{NO}}\right)$ was compared to the information on fertilizer's use retrieved during 412 semi-structured interviews. In Figure 11 the isotopic compositions of the samples do not show a dominance 413 of mineralized synthetic fertilizers as contaminants (as also evidenced in Figure 8a), coherently with the 414 information provided by interviewed wells owners. Denitrification processes are observed in both aquifers, 415 following two trends: one originated from fertilizers (dashed brown oval in Figure 11) and one (dashed blue 
oval in Figure 11) from anthropogenic organic matter, confirming the previously described dual origin of 417 nitrate contamination in the region. This supports the theory that agricultural activities are not the unique 418 cause of aquifer pollution and that significant contribution also come from domestic activities, and specifically 419 from the lack of adequate sanitation facilities in the rural and peri-urban zones For example sample number 4206 , which shows a composition fitting in the field of anthropogenic organic matter (i.e. manure or septic system 421 effluents in Figure 11), belongs a site where the farmer declared to use only synthetic fertilizers, and 422 consequently this contamination should have a civil origin.

423

424

425

426

427

428

429

430

431

432

433

434

435

436

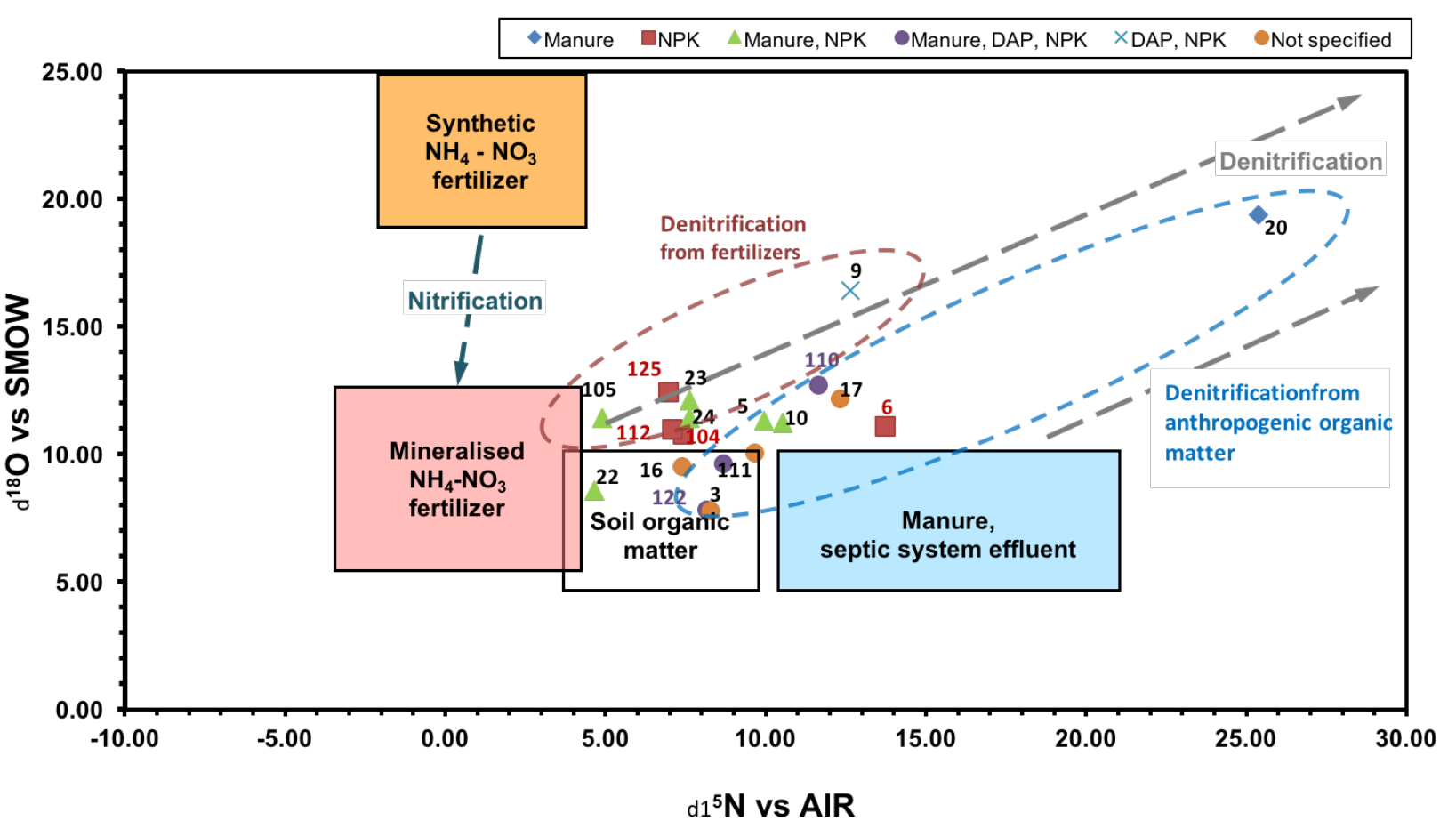

Figure 11. Stable isotope composition of dissolved nitrates in groundwater from the Grombalia Basin, with ranges for groundwater with $\delta^{18} \mathrm{O}_{\mathrm{H} 2 \mathrm{O}} \sim-4$ VSMOW. Modified after Clark and Fritz (1997) and Kendall et al. (2007). Dashed brown and blue oval corresponds to the denitrification trend originated from fertilizers and anthropogenic organic matter respectively.

\section{Science-based management implications}

Results of the socio-hyrogeological investigation performed in the Grombalia aquifer have important implication for the local water management.

The clear identification of pollution origin crucial for drawing new science-based reductions measures. To this end both the hydrogeochemical and social data have proved to be fundamental for the contamination source characterization, supporting the need for integrated investigations: socio-hydrogeology can hence be used to 
437 integrate vulnerability assessment, especially in areas with intense anthropization, and might be considered 438 as an asset in any hydrogeological investigation.

439 In particular, the study demonstrates the added value of socio-hydrogeology compared to classical 440 hydrogeological assessment (Figure 12). The integrated analysis permitted to better constraint the nitrate 441 contamination sources in the studied region. Previous studies, where only hydrogeochemical analyses were 442 performed, generally attributed nitrate contamination to agricultural activities, and particularly synthetic 443 fertilizers, given the dominant land use in the region. However, the information retrieved with the interviews to 444 local farmers and well owners revealed that farmers use manure in combination to synthetic fertilizers. The 445 isotopic investigation also confirmed the presence of manure-induced contamination and highlighted the dual 446 origin (urban/domestic and agricultural) of nitrate. In addition, a more detailed land-use analysis, also coupled 447 with the interview administration, demonstrated that higher concentrations are found in more densely 448 populated areas, evidencing the relevance of domestic pollution especially in the shallow aquifer. Indeed, 449 only with the integrated approach the correct attribution of nitrate contamination would be possible, avoiding 450 the implementation of improper management actions or penalizing farmers. The study also highlights the 451 need to foster better sanitation and waste management at local and regional level. Therefore, results will be 452 adequately shared with competent authorities to support new actions plans in the region.

453 As concerns the implementation of new management practices, it will be of paramount importance to take 454 into account both the needs of the local stakeholders (including managers and water-end users) and the 455 outcomes of the integrated socio-hydrogeological assessment. To this end, results will be shared with the 456 key-stakeholders identified at the early stages of the project by means of a Social Network Analysis: the so 457 called Groups of Agricultural Development (GDAs; composed by landowners, farmers and water users 458 sharing water resources in each irrigated area, and coordinated by a board of democratically elected local 459 members), the Regional Commissariat for Agricultural Development (CRDA, i.e. the institution responsible for 460 water resource management and control in the Grombalia region), and representatives of local farmers 461 (Tringali et al., 2017). For the identification of a new and shared strategy for long-term groundwater protection 462 priority will be given to the identification of new actions for groundwater protection that will not compromise 463 the farmer's wellbeing and productivity and that will take into account the contribution of domestic and urban 464 contamination sources. In this process the role of scientist and local mediators will also be fundamental to 465 ensure adequate information sharing to the general public and civil society. 


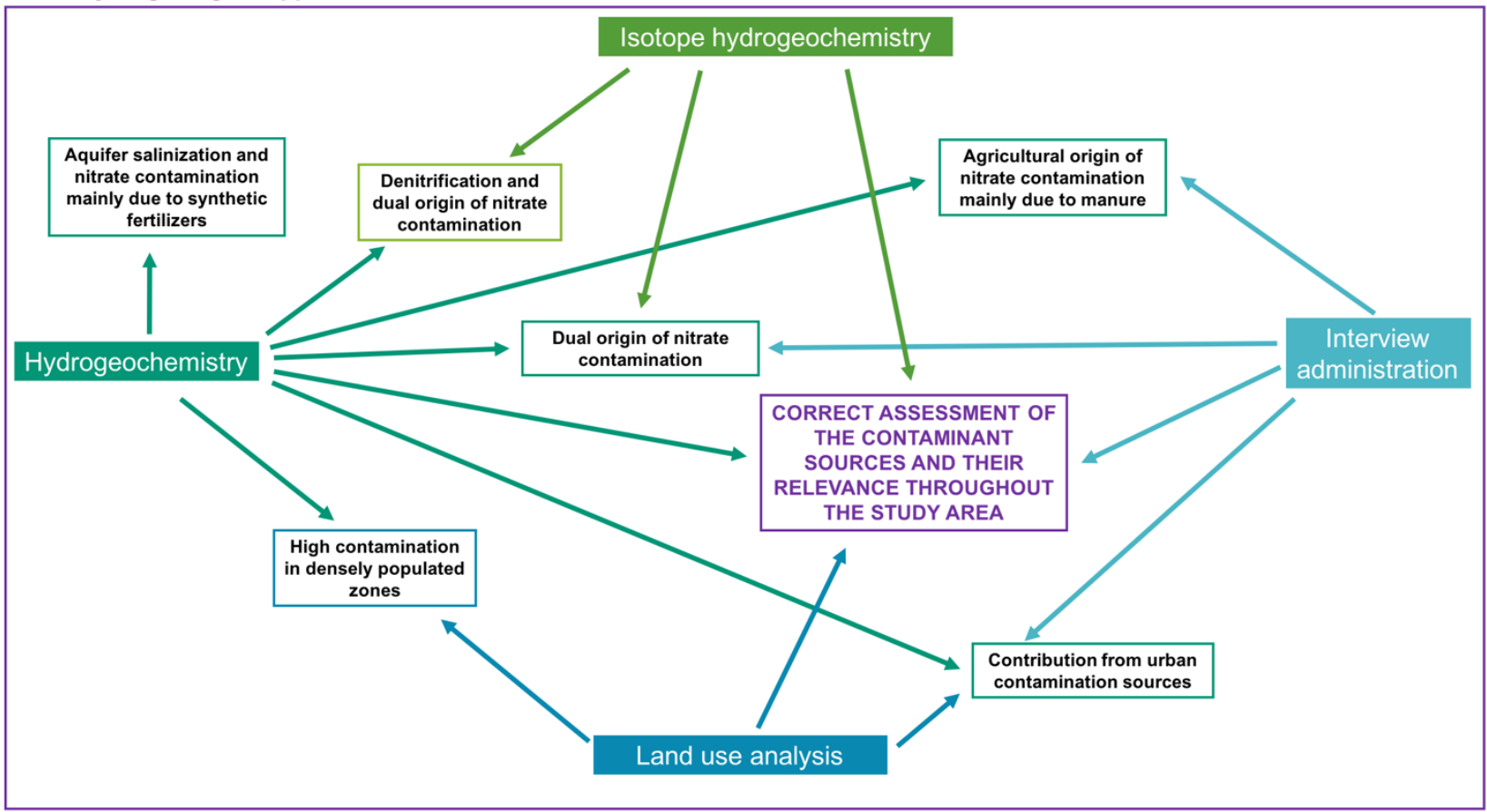

Figure 12. Highlights of the information provided by integrating the different components of the socio-hydrogeological approach. The filled boxes indicate the activity, the empty boxes the conclusions that may be reached using the information provided by the activities. Partial or incorrect conclusions can be obtained if using only $\mathbf{2}$ or $\mathbf{3}$ information activities.

\section{Conclusions}

The Grombalia basin is characterized by a general high nitrate concentration, in both the shallow and deep aquifers. Results of an integrated investigation performed between February and March 2014 coupling hydrogeochemistry and isotope geochemistry highlighted the presence of a dual origin of such contamination, associated to both agricultural and urban activities, in a region where only synthetic fertilizers were generally identified as the main source of nitrate pollution. The presence of high nitrate contents also in the deep aquifer demonstrate its vulnerability to anthropogenic contamination and points to a hydraulic connection with the shallow aquifer for either natural (e.g. presence of discontinuities in the clay layer separating the two) or anthropogenic reasons (e.g. multilayer wells). This evidence would require further investigation as it is a crucial issue for the sound groundwater management in the area.

Interview administration provided useful information supporting the hydrogeochemical analysis, and, as in the case of fertilizers use, in agreement with the findings of the isotopic assessment. Indeed, when budget limitations do not permit a full isotopic assessment, public engagement activities could represent a useful tool to provide insight on possible contamination sources. Coherently, public engagement and capacity building are fundamental to inform farmers and households on the impact of agricultural practices and domestic activities (also with regard to the long-term health and food security implications) as well as to assess their needs and perceptions of environmental issues. 
Overall, results of the investigation performed in the Grombalia basin supported the necessity to perform integrated investigations to correctly assess contaminant sources and their relevance throughout the study area. Multidisciplinary approaches, that also include socio-economic analysis can permit fostering connection between providers and users of water science, also including decision makers. In fact, for a correct long-term management of groundwater resources not only it is fundamental to know the hydrogeological characteristics of the studied region and the causes of aquifer contamination, but also to understand the socio-economic drivers that lead to such contamination. For example, only through public engagement it will be possible to understand if and why farmers over apply nutrients, or whether lacking sanitation facilities are still dominant. Additionally, this information could guide new policies prescriptions targeted to contamination reduction that also take into account the needs and issues of water end-users. Indeed, through socio-hydrogeology (ground)water scientists can act as advocates for good governance, and effectively contribute solving nitrate contamination issues.

501

\section{Acknowledgements}

This research is supported by a Marie Curie International Outgoing Fellowship awarded to Dr. Viviana $\operatorname{Re}$ within the EU 7th FP for Research and Technological Development (FP7-PEOPLE-2012-IOF n. 327287). The authors wish to thank Mr. Jihed Henchiri for the support provided with interviews and fieldwork. The authors gratefully acknowledge the contribution of the staff members of Nabeul Water Resources Division for their help during fieldwork. We thank Dr. Tomas Lovato and Ms. Marianna Anichini for the critical comments of

508 statistical data interpretation. We are grateful to Dr. Enrico Allais and ISO4 private laboratory, for the help in the chemical and isotope analysis.

\section{References}

512 Aravena, R., Evans, M.L., Cherry, J.A., 1993 Stable isotopes of oxygen and nitrogen in source identification of nitrate from septic tanks. Ground Water. 31,180-186.

514 Baily, A., Rock, L., Watson, C.J., Fenton, O., 2011. Spatial and temporal variations in groundwater nitrate at 515 an intensive dairy farm in south-east Ireland: insights from stable isotope data. Agric. Ecosys. Environ. $516 \quad 144,308-318$.

517 Ben Ayed, N., 1993. Évolution tectonique de l'avant-pays de la chaîne alpine de la Tunisie du début du 518 Mésozoïque à l'Actuel. Thèse d'État Uni. Paris-11, Orsay, Publ. Office Nat. Mines Tunis.

519 Ben Salem, H., 1995. Évolution de la péninsule du cap Bon (Tunisie orientale) au cours du Néogène, Notes $520 \quad$ Serv. Geol. Tunisie 61, 73-84.

521 Ben Moussa, A., 2007. Caractérisation hydrogéologique hydrochimique et isotopique de nappe phréatique de 522 Grombalia, Master, Université de Sfax, Tunisie. 
Ben Moussa, A., Salem, S.B.H., Zouari, K., 2010. Hydrochemical and isotopic investigation of the groundwater composition of an alluvial aquifer, Cap Bon Peninsula, Tunisia. Carbonates and Evaporites 25,161-176.

Ben Moussa, A. and Zouari, K., 2011. Hydrochemical Investigation of Groundwater Contamination in the Grombalia Shallow Aquifer, Cap Bon Peninsula, Tunisia: impact of Irrigation with Industrial Waste Water. Waste Water - Evaluation and Management, Prof. Fernando SebastiÃ $j n$ GarcÃa Einschlag (Ed.), ISBN: 978- 953-307-233-3, InTech, Available from: http://www.intechopen.com/books/waste-water-evaluationand-management/hydrochemical-investigation-of-groundwater-contamination-in-the-grombalia-shallowaquifer- cap-bon-pe.

Ben Moussa, A., Zouari, K., Valles, V., Jlassi, F., 2012. Hydrogeochemical Analysis of Groundwater Pollution in an Irrigated Land in Cap Bon Peninsula, North-Eastern Tunisia. Arid Land Research and Management Ben Hamouda MF, Tarhouni J, Leduc C, Zouari K (2011) Understanding the origin of salinization of the Plio-quaternary eastern coastal aquifer of Cap Bon (Tunisia) using geochemical and isotope investigations. Environmental Earth Sciences 63:889-90126:1-14.

Bose, B., Srivastava H.S., 2001. Absorption and accumulation of nitrate in plants: Influence of environmental factors. Indian journal of experimental biology 39:101-110.

Busche, D., 2015. Coordination between Research and Implementation in Integrated Water Resources Management - Jordan as a case study. In: Fayyad, M., Sandri, S., Weiter M., Zikos, D. (Eds), Social Water Studies in the Arab Region State of the Art and Perspectives. Seminar für Ländliche Entwicklung (SLE) Entwicklungspolitische Themenreihe des SLE, Band 4. Berlin, 2015.

Castany, G., 1948. Les fossés d'effondrement de Tunisie, Géologie et hydrologie. Plaine de Grombalia et

Charfi, S., Trabelsi, R., Zouari, K., Chkir, N., Charfi, H., Rekaia, M., 2013. Isotopic and hydrochemical investigation of the Grombalia deep aquifer system, northeastern Tunisia. Carbonates Evaporites 28: $281-295$.

Chenini, I., Zghibi, A., Kouzana, L., 2015. Hydrogeological investigations and groundwater vulnerability assessment and mapping for groundwater resources protection and management : State of the art and a case study. Journal of African Earth Sciences. $109: 11-26$.

Chihi, L., 1995. Les fossés néogènes à quaternaires de la Tunisie et de la mer Pélagienne: une étude structurale et une signification dans le cadre géodynamique de la Méditerranée centrale. Thèse d'État,

554 Clark, I., and Fritz, P., 1997. Environmental Isotopes in Hydrogeology. CRC Press. pp. 328.

555 Colleuil, B., 1976. Etude stratigraphique et néotectonique des formations néogènes et quaternaires de la 556 région de Hammamet-Nabeul (Cap Bon) D.E.S. Université de Nice 
Deme, I, Tandia, A.A., Faye, A., Malou, R., Dia, I., Diallo, M.S., Sarr, M., 2006. Management of nitrate pollution of groundwater in African cities: the case of Dakar, Senegal. In: Xu Y, Usher BH (eds) Groundwater pollution in Africa. Balkema, Leiden, The Netherlands, pp 181-192.

DGRE (Direction Générale des Ressources en Eau), 2006. Annuaire de l'exploitation des nappes phréatique de la Tunisie. DGRE, Tunis, Tunisie.

DGRE (Direction Générale des Ressources en Eau), 2010. Annuaire de l'exploitation des nappes phréatique de la Tunisie. DGRE, Tunis, Tunisie.

Diédhiou, M., Cissé Faye, S., Diouf, O. C., Faye, S., Faye, A., Re, V., Wohnlich, S., Wisotzky, F., Schulte, U., Maloszewski, P., 2012. Tracing groundwater nitrate sources in the Dakar suburban area: an isotopic multitracer approach. Hydrological Processes. 26, 760-770 (doi:10.1002/hyp.8172)

Elmejdoub, N. and Jedoui, J., 2009. Pleistocene raised marine deposits of the Cap Bon peninsula (N-E

Ennabli, M., 1980. Etude hydrogéologique des aquifères du Nord-Est de la Tunisie pour une gestion intégrée des ressources en eau. Thèse de Doctorat d'Etat. Nice, 570p.

Fan, A.M., and, Steinberg, V.E., 1996. Health implications of nitrate and nitrite in drinking water: an update on methemoglobinemia occurrence and reproductive and developmental toxicity. Regul Toxicol Pharmacol. 23:35-43.

Food and Agriculture Organization of the United Nations (FAO), 1996. Control of water pollution from agriculture - FAO irrigation and drainage paper 55.

Foster, S., Chilton, J., 2003. Groundwater: the process and global significance of aquifer degradation. Phil. Trans. R. Soc. Lond. B. 358, 1957-1972.

Gafsi, M.H. and Ben Hadj, M.S., 2007. Tunisie: Rapport Diagnostic. (www.project-

Gaaloul, N., Candela, L., Chebil. A., Soussi, A., Tamoh, K., 2014. Groundwater flow simulation at the Grombalia phreatic aquifer (Cap Bon, Northeastern Tunisia). Desalination and Water Treatment. 52, 1997-2008. destinations.org/docs/WEB\%20TUNISIE\%20-\%20Rapport\%20Diagnostic.pdf) (accessed on 20 February 2015).

Gonfiantini, R., Stichler, W., Rozanski, K., 1995. Standards and Intercomparison Materials Distributed by International Atomic Energy Agency for Stable Isotope Measurements: Reference and intercomparison 
Hadj Sassi, M., Zouari, H., Jallouli, C., 2006 Contribution de la gravimétrie et de la sismique réflexion pour une nouvelle interprètation géodynamique des fossés d'effondrement en Tunisie : exemple du fossé de Grombalia. Compt Rend Géosc. 338, 751-756.

INM - National Institute of Meteorology of Tunisia, 2014. Tableaux climatiques mensuels. Archive INM pour la période de 2003-2012. Station Nabeul.

Kammoun, S., Trabelsi, R., Re, V., Zouari, K., Henchiri, J., submitted. Groundwater quality assessment in semi arid regions using integrated hydrogeochemical, isotopic and statistical approaches: the case of Grombalia aquifer (N-E Tunisia). Submitted to Environmental Earth Sciences.

Keeney, D.R., 1989. Sources of nitrate to groundwater. In: R.F. Follett (Editor), Nitrogen Management and Groundwater Pollution. Elsevier, Amsterdam, pp. 23-34.

Kendall, C, Elliott, E.M., Wankel, S.D., 2007. Tracing anthropogenic inputs of nitrogen in ecosystems. In: Michener, R, and Lajtha, K (Eds.), Stable Isotopes in Ecology and Environmental Science (second ed.), Blackwell Publishing Inc., Oxford, UK,375-449.

Liu, G.D., Wu, W.L., Zhang, J., 2005. Regional differentiation of non-point source pollution of agriculture nitrate nitrogen in groundwater in northern China. Agric. Ecosyst. Environ, 107: 211-220.

McLean, W., Jankowski, J., Lavitt, N., 2000. Groundwater quality and sustainability inalluvial aquifer, Australia. In: Sililoo, O., et al. (Eds.), Groundwater, Past Achievement and Future Challenges. Balkema, Rotterdam, pp. 567e573.

Morris, B.L., Lawrence, A.R.L, Chilton, P.J.C, Adams, B., Calow R.C., Klinck, B.A., 2003. Groundwater and its Susceptibility to Degradation: A Global Assessment of the Problem and Options for Management. Early Warning and Assessment Report Series, RS. 03-3. United Nations Environment Programme, Nairobi, Kenya.

Panno, S.V., Hackley, K.C., Hwang, H.H., Kelly, W.R., 2001. Determination of the sources of nitrate

$615 \mathrm{Re}, \mathrm{V} ., 2$ 2015. Incorporating the social dimension into hydrogeochemical investigations for rural development:

616 the Bir Al-Nas approach for socio-hydrogeology. Hydrogeology Journal, 23, 1293-1304 617 (doi:10.1007/s10040-015-1284-8).

$618 \mathrm{Re}, \mathrm{V}$ and Sacchi, E., 2017. Tackling the salinity-pollution nexus in coastal aquifers from arid regions using 619 nitrate and boron isotopes. Environmental Science and Pollution Research (in press; DOI: 10.1007/s11356-017-8384-z). 
Re, V., Cissé Faye, S., Faye A., Faye, S., Gaye, C.B., Sacchi, E., Zuppi, G.M., 2011. Water quality decline in coastal aquifers under anthropic pressure: the case of a suburban area of Dakar (Senegal). Environmental Monitoring and Assessment, 172, 605-622 (doi:10.1007/s10661-010-1359-x).

624 Sacchi, E., Acutis, M., Bartoli, M., Brenna, S., Delconte, C.A., Laini, A., Pennisi, M., 2013. Origin and fate of 625 nitrates in groundwater from the central Po plain: insights from isotopic investigations. Appl Geochem $626 \quad 34: 164-180$

Shand, P., Edmunds, W.M., 2008. The baseline in organic chemistry of European groundwaters. In: Natural groundwater quality, Edmunds and Shanf (Eds.). Blackwell Publishing Inc., Oxford, UK,22-25.

Schoeller, H., 1939. Le quaternaire du Golfe ancien de Grombalia. Tunisie. Actes ociété Linnéenne de Bordeaux 91, 14-30.

Siebert, S., Henrich, V., Frenken, K. and Burke, J., 2013. Update of the Digital Global Map of Irrigation Areas (GMIA) to Version 5. Rome/Bonn, Germany, Food and Agriculture Organization of the United Nations (FAO)/University of Bonn.

Silva, S.R, Kendall, C., Wilkinson, D.H., Ziegler, A.C., Chang, C.C.Y, Avanzino, R.J., 2000. A new method for collection of nitrate from fresh water and the analysis of nitrogen and oxygen isotope ratios. J. Hydrol., 228: $22-36$.

Singh, B., Singh, Y., Sekhon, G.S., 1995. Fertilizer-N use efficiency and nitrate pollution of groundwater in developing countries. Journal of Contaminant Hydrology, 20, 167-184.

Sivapalan, M., Savenije, H., Bloeschl, G., 2012. Sociohydrology: A new science of people and water. Hydrological Processes, 26:1270-1276. doi:10.1002/hyp.8426.

Tlili-Zrelli, B., Hamzaoui-Azaza, F., Gueddari, M., Bouhlila, R., 2013. Geochemistry and quality assessment of groundwater using graphical and multivariate statistical methods. A case study: Grombalia phreatic aquifer (Northeastern Tunisia). Arabian Journal of Geosciences, 6: 3545-3561.

Tredoux, G., Engelbrecht, P., Israel, S., 2009. Nitrate in groundwater - Why is it a hazard and how to control it? Report to the Water Research Commission by CSIR, Natural Resources and the Environment, Stellenbosch.

Tringali C., Re V., Siciliano G., Chkir N., Tuci C., Zouari K., 2017. Insights and participatory actions driven by a socio-hydrogeological approach for groundwater management: the Grombalia Basin case study (Tunisia). Hydrogeology Journal (in press; DOI: 10.1007/s10040-017-1542-z).

UNICEF and WHO, 2012. Progress on Drinking Water and Sanitation: 2012 Update.

World Health Organization, 2011. Guidelines for drinking-water quality, fourth edition. ISBN 978924154815 1. 
653 World Health Organization (WHO), 2011. Guidelines for drinking-water quality. World Health Organization. 654 Geneva, Switzerland: WHO

655 World Water Assessment Programme of the United Nations (WWAP), 2016. The United Nations World Water

656 Development Report 2016: Water and Jobs. Paris, UNESCO.

657 Yu, X., Geng, Y., Heck, P., Xue, B., 2015., A Review of China's Rural Water Management. Sustainability, 7 :

658 5773-5792. doi:10.3390/su7055773.

661 Figure 1. Location of the Grombalia Basin. Background satellite image from Microsoft ${ }^{\circledR}$ Bing $^{\mathrm{TM}}$ Maps. The white rectangle highlights the area represented in Figure 2.

663 Figure 2. Location of the sampling sites: (A) shallow aquifer; (B) deep aquifer.

664 Figure 3. Piper diagram in rectangular coordinates (Modif. After Ray and Mukherjee, 2008) for the samples collected between February and March 2014 in the shallow and deep Grombalia aquifers.

666 Figure 4. Box plots of the major ion contents for the shallow and deep aquifers in the Grombalia basin.

667 Figure 5. (A) Plot of $\mathrm{Na}$ vs $\mathrm{Cl}$ and (B) Ca vs SO4. Dashed blue line: Seawater mixing trend; Purple and cyan 668 dashed lines correspond to the regressions for the shallow and deep aquifers respectively $\left(\mathrm{Na}=0.6036^{*} \mathrm{Cl}+\right.$ $6693.0061, \mathrm{R}^{2}=0.903$ and $\left.\mathrm{Na}=0.8342^{*} \mathrm{Cl}+0.8607, \mathrm{R}^{2}=0.962\right)$.

670 Figure 6. (Na+K)-Cl versus ( $\mathrm{Ca}+\mathrm{Mg})-(\mathrm{HCO3+SO4).} \mathrm{Black} \mathrm{line:} \mathrm{cation} \mathrm{exchange} \mathrm{(-1:} \mathrm{1)} \mathrm{line.}$ Figure 7. Nitrate concentration distribution map in the Grombalia Basin: (A) shallow aquifer, (B) deep aquifer.

672 Figure 8. (A) Nitrate concentration vs $\delta^{15} \mathrm{~N}$. The reported ranges for nitrogen pollution sources are based on 673 Clark and Fritz, 1997). (B) $\delta^{15} \mathrm{~N}$ vs InNO3, with the possible denitrification trends identified for synthetic (red 674 arrow) and organic (blue arrow) nitrogen sources.

675 Figure 9. Nitrate versus chloride concentrations for the samples collected in the Grombalia Basin in the 676 February-March 2014 campaign. Orange dashed line: WHO (2011) statutory limit for drinking water (50 mg/L).

677 Figure 10. Nitrate concentrations versus well depth.

678 Figure 11. Stable isotope composition of dissolved nitrates in groundwater from the Grombalia Basin, with ranges for groundwater with $\delta^{18} \mathrm{O}_{\mathrm{H} 2 \mathrm{O}} \sim-4$ VSMOW. Modified after Clark and Fritz (1997) and Kendall et al. (2007). Dashed brown and blue oval corresponds to the denitrification trend originated from fertilizers and anthropogenic organic matter respectively.

682 Figure 12. Highlights of the information provided by integrating the different components of the socio683 hydrogeological approach. The filled boxes indicate the activity, the empty boxes the conclusions that may be 684 reached using the information provided by the activities. Partial or incorrect conclusions can be obtained if 685 using only 2 or 3 information activities.

688 Table 1. Summary of the structure and information retrieved with the structured questionnaires proposed by Re 689 (2015). 
690 Table 2. Descriptive statistics and Mann-Whitney $U$ test results. Concentrations are expressed in mg/L, while

691 isotopic values as permil. Underlined values correspond to not-statistically significant parameters. Values in

692 bold indicate the group with the highest mean ranks relative to each statistically significant parameter.

693 Table 3. Summary of the information retrieved with the structured interviews administered during the in situ 694 measurements. Percentages indicated as "out of total" take into account that for some categories responses are

695 higher to the number of respondents (i.e. corresponding to possibility to have multiple groundwater use and 696 crop production in the same site).

\section{Supplementary data}

700 Table X1 Physico-chemical parameters, geochemical and isotopic results of the waters collected in the shallow 701 and deep Grombalia aquifers between February and March 2014. Samples highlighted in red have NO3 702 concentrations exceeding the WHO statutory limit for drinking water (WHO, 2011). 